\title{
Revision of the Oligocene bryozoan taxa described by Stoliczka (1862), with the description of a new genus of Bryocryptellidae
}

\author{
Kamil ZÁGORŠEK \\ Department of Geography, Technical University of Liberec \\ Studentská 2, CZ-461 17 Liberec (Czech Republic) \\ kamil.zagorsek@gmail.com \\ Dennis P. GORDON \\ Marine Biodiversity \& Biosecurity, \\ National Institute of Water \& Atmospheric Research, \\ Private Bag 14901, Kilbirnie, Wellington, (New Zealand) \\ dennis.gordon@niwa.co.nz
}

\section{KEY WORDS \\ Bryozoa, \\ Oligocene, \\ Germany, \\ lectotypification, \\ new genus,}

new combinations.
Zágoršek K. \& Gordon D. P. 2014. - Revision of the Oligocene bryozoan taxa described by Stoliczka (1862), with the description of a new genus of Bryocryptellidae. Geodiversitas 36 (4): 541-564. http://dx.doi.org/10.5252/g2014n4a3

\begin{abstract}
A collection of bryozoans from the Oligocene of Latdorf, Germany, first described by Ferdinand Stoliczka in 1862 and not examined since, has been reexamined. Stoliczka had recognized 47 species, 24 of them new. Of these latter, 14 names remain valid; the remainder are synonyms of previously described taxa or, owing to the originally inadequate state of the fossil material examined, taxonomically indeterminable. The genera Orbitulipora Stoliczka, 1862 and Stichoporina Stoliczka, 1862, both introduced by Stoliczka in 1862 along with their type species, are still valid. Two of his species, one of which had not been examined since its first description, comprise a new bryocryptellid genus, Stoliczkella n. gen., which superficially resembles the celleporid genus Galeopsis Jullien \& Calvet, 1903. Diagnoses or descriptions are provided herein for all of the taxa in the collection and lectotypes selected. The results of this revision will be applied to a forthcoming analysis of a recent extended excavation of the Latdorf section by the University of Leipzig, in which bryozoans are among the most abundant fossil groups.
\end{abstract}




\section{MOTS CLÉS \\ Bryozoa, \\ Oligocène, \\ Allemagne, \\ lectotypification, \\ genre nouveau, \\ combinaisons nouvelles.}

\section{RÉSUMÉ}

Révision des bryozoaires oligocènes décrits par Stoliczka (1862), avec la description d'un nouveau genre de Bryocryptellidae.

Une collection de bryozoaires de l'Oligocène de Latdorf, Allemagne, initialement décrite par Ferdinand Stoliczka en 1862 et jamais revue depuis, a été réexaminée. Stoliczka avait reconnu 47 espèces, dont 24 nouvelles. Parmi ces dernières, 14 noms restent acceptables, les autres sont des synonymes de taxons déjà décrits ou, de taxonomie indéterminable en raison du mauvais état d'origine du matériel fossile. Les genres Orbitulipora Stoliczka, 1862 et Stichoporina Stoliczka, 1862, tous deux introduits par Stoliczka en 1862 avec leur espèce type, sont toujours acceptables. Deux de ses espèces, dont l'une n'avait pas été examinée depuis sa première description, comprennent un nouveau genre de Bryocryptellidae, Stoliczkella n. gen., qui ressemble superficiellement à Galeopsis Jullien \& Calvet, 1903 (Celleporidae). Ici, les diagnostics et descriptions sont fournis pour tous les taxons de la collection et les lectotypes sélectionnés. Les résultats de cette révision seront utilisés pour l'analyse d'une extension récente de l'excavation de la coupe de Latdorf, entreprise par l'Université de Leipzig, dans lequel les bryozoaires sont parmi les groupes de fossiles les plus abondants.

\section{INTRODUCTION}

Stoliczka (1862) described bryozoans from a fossil locality at Latdorf, Saxony-Anhalt, Germany, recognizing 47 species, 24 of them new, and ascribing an Oligocene age to the section. As is usual for many publications from the 19th century, the quality of illustrations and species descriptions is frequently inadequate for modern determination. Recently, an extended excavation of the Latdorf section was undertaken by the University of Leipzig (Institut für Geophysik und Geologie, GeologischPalaeontologische Sammlung). Bryozoans turned out to be among the most abundant fossil groups, but, in order to evaluate their taxonomic composition, and to contribute to a better understanding of the overall paleontological significance of the site, it has proven necessary to examine the type material of the species described by Stoliczka (1862). The main purpose of this paper is to revise Stoliczka's collection and, at the same time, provide a basis for the inclusion of this group of colonial suspension-feeding organisms in a later paleoecological analysis of the faunal components of the section.

\section{MATERIAL AND METHODS}

Thanks to the EU project Synthesys (AT-TAF-2647) one of us (KZ) was able to access the type collection of Stoliczka (1862) stored in the Natural History Museum in Vienna (NHMV). The collection is in good condition and all type material examined is properly labelled. Specimens were cleaned briefly (several seconds) in an ultrasonic cleaner before initial study by optical microscopy and preliminary taxonomic assessment. During this preliminary study an attempt was made to match type specimens with Stoliczkàs (1862) illustrations. If the type collection included more than one specimen per species, a lectotype was selected that either most closely resembled the illustration made by Stoliczka (1862) or (if no such specimen could be found) was the best-preserved colony.

Selected specimens from among those showing sufficient preservation and important features were studied using SEM (Jeol, type JSM 6610 LV). The specimens were temporarily mounted on adhesive carbon disks and observed without coating in a lowvacuum regime. SEM micrographs were processed using CorelDraw $\mathrm{X}^{\circ}$ software to produce the final illustrations. 
Our taxonomic and nomenclatural revision of the type collection is summarized in Table 1 . Detailed description of all species described as new by Stoliczka (1862) follows, using taxonomically revised binominals where necessary. We illustrate those specimens that we regard as definitely intended by Stoliczka to represent his new taxa.

\section{SYSTEMATICS}

Phylum BRYOZOA Ehrenberg, 1831

Class STENOLAEMATA Borg, 1926

Order CYCLOSTOMATA Busk, 1852

Family TUBULIPORIDAE Johnston, 1838 Genus Exidmonea

David, Mongereau \& Pouyet, 1972

Exidmonea hoernesi (Stoliczka, 1862) (Fig. 1A)

Idmonea (Tubigera) hörnesi Stoliczka, 1862: 82, pl. 1, fig. 7.

Exidmonea hoernesi - Zágoršek 2003: 111, pl. 2, fig. 3 (cum syn.).

Material eXAmined. - Holotype, registered as 1862/0022/0050.

DiAGNOSIS. - Four zooecia in each fascicular row, fascicles not alternating. One aperture, close to the dorsal side, always arranged outside the fascicle. Apertures rectangular, with short narrow peristome. Zooecial tubes perforated by pseudopores. Dorsal side of colony slightly ribbed and convex. No gonozooecium developed.

\section{REMARKS}

Although no gonozooecia have been found, the presence of one aperture, close to the dorsal side of the colony, which is always arranged outside the fascicle is diagnostic, allowing positive identification.

\section{Exidmonea giebeli (Stoliczka, 1862)}

(Fig. 1B)

Idmonea giebeli Stoliczka, 1862: 81, pl. 1, fig. 6 (v).

Exidmonea giebeli - Zágoršek 2003: 110, pl. 2, figs 4, 5 (cum syn.).
Material examined. - Holotype, registered as 1859/0026/0144.

Diagnosis. - Colony with triangular transverse section, the angle between the frontal sides $c .120^{\circ}$. Fascicles comprising pairs of apertures with 1 additional aperture situated close to median area of frontal side of colony. Dorsal side of colony flat or rarely slightly convex, perforated by pseudopores, with slight outline of zooecial tubes. Gonozooecium not observed.

\section{REMARKS}

The species is similar to Ybseloecia typica (Manzoni, 1878) but differs in the presence of an additional aperture situated between the pairs of fasciculate apertures, in the middle of the frontal side of the colony. This seems to be diagnostic for the species. Although the absence of a gonozooecium can make species identification problematic, the presence of median rows of autozooecia not belonging to a fascicle is also a specific feature. The species name was used also by Zágoršek (2010) to accommodate Miocene Exidmonea with median rows of autozooecia in very wide, low-profile branches.

Due to the gently convex frontal surface and absence of keel separating two fascicles, the species may belong also to genus Nevianipora Borg, 1944. Without a well-preserved gonozooecium, these two genera cannot be clearly distinguished, so the generic attribution of the species remains uncertain.

\section{Family OnCousoecindae Canu, 1918 Genus Filisparsa d'Orbigny, 1853}

Filisparsa? sp.

(Fig. 1C, D)

Filisparsa tenella Stoliczka, 1862: 80, pl. 1, fig. 5. —Zágoršek 2001: 519; 2003: 115, pl. 2, fig. 6 (cum syn.).

MATERIAl EXAMINED. - Holotype of Filisparsa tenella, registered as 1862/0022/0049.

DIAGNOSIS. - Colony short, erect, with autozooecial apertures arranged in rows. Peristomes slightly curving laterally from colony axis. Frontal wall with pseudopores; boundaries between autozooecial tubes indistinct. Dorsal side of colony smooth, slightly ribbed. Gonozooecium not known. 
TABLE 1. - Taxonomic and nomenclatural revision of the type collection of Oligocene bryozoan taxa described by Stoliczka (1862).

\begin{tabular}{|c|c|c|c|}
\hline Original name & Ref - NHM Vienna & Proposed new name & Fig. \\
\hline Idmonea (Tubigera) hoernesi & $1862 / 0022 / 0050$ & Exidmonea hoernesi & \\
\hline Idmonea (Tubigera) giebeli & $1859 / 0026 / 0144$ & Exidmonea giebeli & $1 \mathrm{~A}$ \\
\hline Filisparsa tenella & $1862 / 0022 / 0049$ & Filisparsa? sp. & \\
\hline Pustulopora (Clausa) retifera & $1862 / 0022 / 0047$ & Mecynoecia cf. pulchella & \\
\hline Pustulopora attenuata & 2010/259/16A & Mecynoecia cf. proboscidea & \\
\hline Alveolaria buski & $1862 / 0022 / 0055$ & ?Bobiesipora fasiciculata & \\
\hline Heteropora similis & $1859 / 0026 / 0138$ & $\begin{array}{l}\text { "Heteropora similis Stoliczka, 1862" } \\
\text { nomen dubium }\end{array}$ & $1 \mathrm{~J}$ \\
\hline Hornera porosa & $1862 / 0022 / 0048$ & Hornera cf. verrucosa & \\
\hline Pavotubigera anhaltina & $1862 / 0022 / 0052$ & $\begin{array}{l}\text { "Disporella anhaltina (Stoliczka, 1862)" } \\
\text { nomen dubium }\end{array}$ & $1 \mathrm{~K}, \mathrm{~L}$ \\
\hline Lunulites latdorfensis & $1867 / 0012 / 0018$ & Lunulites latdorfensis & 1B-F \\
\hline Membranipora (Semiflustrella) anhaltina & $1862 / 0022 / 0054$ & Onychocella subpyriformis & \\
\hline Eschara reussi & $1859 / 0026 / 0136$ & Steginoporella cf. reingruberhohensis & $2 \mathrm{~A}$ \\
\hline Eschara (Escharifora) ornatissima & $2010 / 0259 / 0010$ & Adeonella ornatissima & 2B-D \\
\hline Eschara (Escharifora) mortisaga & $1859 / 0026 / 0137$ & Adeonella mortisaga n. comb. & $2 E-F$ \\
\hline Eschara (Porellia) pulchra & $1862 / 0022 / 0056$ & Adeonellopsis pulchra n. comb. & $3 \mathrm{~A}$ \\
\hline Lepralia pedicularis & $1862 / 0022 / 0053$ & $\begin{array}{l}\text { "Lepralia pedicularis Stoliczka, 1862" } \\
\text { nomen dubium }\end{array}$ & $4 \mathrm{~B}$ \\
\hline Eschara (Flustrina) subovata & 2010/0259/0006 & Stoliczkella subovata n. comb. & $3 B-G$ \\
\hline Eschara crenatula & 2010/0259/0007 & Stoliczkella crenatula n. comb. & $4 \mathrm{~A}-\mathrm{F}$ \\
\hline Lepralia macropora & $1859 / 0026 / 0140$ & Anarthropora macropora n. comb. & $5 A-D$ \\
\hline Lepralia grotriani & $1862 / 0022 / 0051$ & Escharella grotriani & $5 \mathrm{E}-\mathrm{F}$ \\
\hline Cellaria beyrichi & $1859 / 0026 / 0133$ & Myriapora? beyrichi n. comb. & $5 \mathrm{G}-\mathrm{H}$ \\
\hline Eschara (Porina) porulosa & 2010/0259/0009 & Tubucella mammillaris & $5 \mid-J$ \\
\hline Retepora fasciata & $1862 / 0022 / 0044$ & $\begin{array}{l}\text { "Retepora fasciata Stoliczka, 1862" } \\
\text { nomen dubium }\end{array}$ & \\
\hline Orbitulipora haidingeri & $1862 / 0022 / 0045$ & Orbitulipora haidingeri & $6 \mathrm{~A}-\mathrm{H}$ \\
\hline Stichoporina reussi & $1862 / 0022 / 0046$ & Stichoporina reussi & $7 \mathrm{~A}-\mathrm{G}$ \\
\hline
\end{tabular}

\section{REMARKS}

Owing to the poor preservation and lack of the gonozooecium, the exact determination remains uncertain, but the arrangement of the autozooecia mostly resembles those in Filisparsa, even though the type species is Cretaceous. There is also some similarity to Tervia serrata (Reuss, 1869) in which, however, the $\mathrm{V}$ outline of the autozooecial tubes is observable on the dorsal side of the branch.

Family Mecrnoeciddae Canu, 1918 Genus Mecynoecia Canu, 1918

\section{Mecynoecia cf. pulchella (Reuss, 1847)} (Fig. 1E)

Cricopora pulchella Reuss, 1847: 40, pl. 6, fig. 10.

Pustulopora (Clausa) retifera Stoliczka, 1862: 78, pl. 1, fig. 2.
Mecynoecia pulchella - Zágoršek 2010: 32, pl. 17, figs 1-8 (cum syn.).

Material examined. - Two colonies of Pustulopora (Clausa) retifera, both lacking a gonozooecium, are registered as 1862/0022/0047. Owing to taxonomic uncertainty, no lectotype of Stoliczka's species has been selected.

DiAGNOSIS. — Colonies branches broken into a short length, with 12-14 autozooecial tubes arranged around branch axis. Tubes narrow, short, with circular to oval aperture. Apertures are very densely arranged, situated on short peristomes. Frontal walls short, slightly convex, smooth, sparsely perforated by small pseudopores. Gonozooecium lacking.

\section{REMARKS}

The arrangement of zooecia very closely resembles that in Mecynoecia pulchella, which is very common in tertiary sediments of Paratethys (see Zágoršek 2010). Insofar as gonozooecia are lacking in any of the Stoliczka specimens, the identification is not certain. 

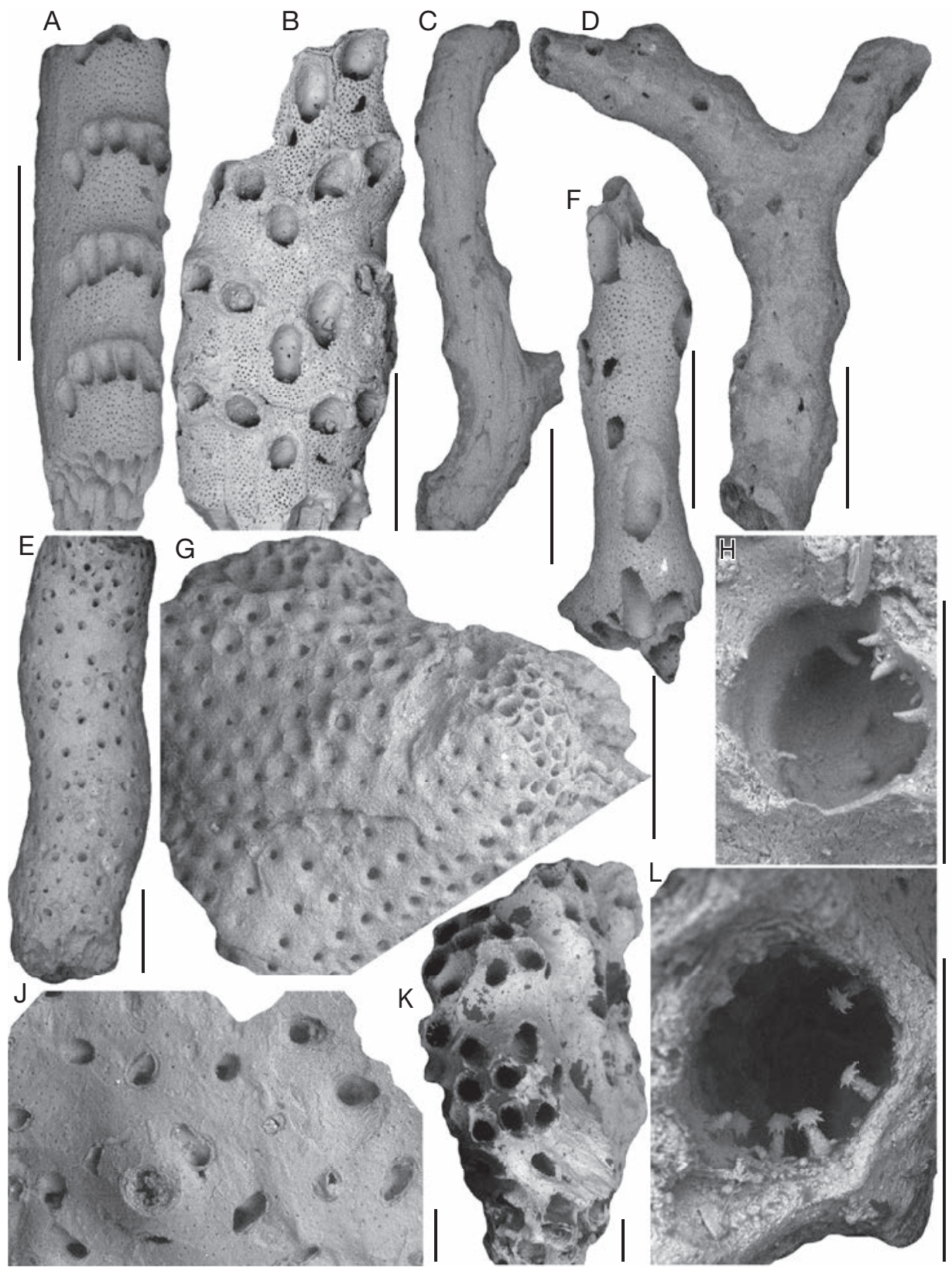

FIG. 1. - A, Exidmonea hoernesi (Stoliczka, 1862), general view of holotype showing diagnostic features: one aperture, close to the dorsal side of the colony, which is always arranged outside the fascicle; B, Exidmonea giebeli (Stoliczka, 1862), general view of holotype; C, D, holotype of Filisparsa tenella identified as Filisparsa? sp. due to the poor preservation and lack of the gonozooecium; E, one of the syntypes of Pustulopora (Clausa) retifera identified as Mecynoecia cf. pulchella (Reuss, 1847) owing to the lack of a gonozooecium; F, holotype of Pustulopora attenuate identified as Mecynoecia cf. proboscidea (Milne-Edwards, 1838) owing to the lack of a gonozooecium; G, H, syntype of Alveolaria Buski identified as ?Bobiesipora fasciculata (Reuss, 1848); J, holotype of Heteropora similis Stoliczka, 1862, identified as nomen dubium due to the very poor preservation and the absence of a gonozooecium or any other characteristic features; K, L, holotype of Pavotubigera anhaltina identified as "Disporella anhaltina (Stoliczka, 1862)" nomen dubium owing to poor preservation and the absence of a gonozooecium. Scale bars: A-G, $1 \mathrm{~mm} ; \mathrm{H}-\mathrm{L}, 100 \mu \mathrm{m}$. 
Mecynoecia cf. proboscidea (Milne-Edwards, 1838) (Fig. 1F)

Pustulopora proboscidea Milne-Edwards, 1838: 219, pl. 12, fig. 2 .

Pustulopora attenuata Stoliczka, 1862: 77, pl. 1, fig. 1.

Mecynoecia proboscidea - Zágoršek 2010: 32, pl. 18, figs 1-5 (cum syn.).

MATERIAL EXAMINED. Holotype of Pustulopora attenuata, registered as 2010/259/16A.

DiAgNOSIS. - Colony with four autozooecial tubes arranged around branch axis. Tubes very long, with circular to oval aperture situated on long peristomes. Frontal walls long, convex. Gonozooecium not developed.

\section{REMARKS}

The arrangement of zooecia very closely resembles that in Mecynoecia proboscidea, which is one of the commonest cyclostomes species in the Eocene (see Zágoršek 2003). Insofar as no gonozooecium is known in any of the Stoliczka specimens, the identification is not certain. Registered as 2010/259/16B are unrecognizable cheilostomes with a similar arrangement of zooecia.

Suborder CERIOPORINA Hagenow, 1851

Family CERIOPORIDAE Busk, 1859

Genus Bobiesipora Vávra, 1977

?Bobiesipora fasciculata (Reuss, 1848)

(Fig. 1G, H)

Apsendesia fasciculata Reuss, 1848: 40, pl. 6, fig. 8.

Alveolaria buski Stoliczka, 1862: 85, pl. 2, fig. 5.

Bobiesipora fasciculata - Zágoršek 2003: 119, pl. 5, fig. 3 (cum syn.).

MATERIAL EXAMINED. - Four syntypes of Alveolaria buski registered as 1862/0022/0055. No lectotype selected.

DiAGNOSIS. - Colony with a large circular encrusting basal part. Branches with zooecial tubes irregularly arranged around base. Branches often bifurcate, perforated by many kenozooecia and apertures in fascicles. Fascicles corresponding with a keel on dorsal surface of colony. Gonozooecium not observed.

\section{REMARKS}

In the absence of a gonozooecium in the Stoliczka specimens, the attribution to Bobiesipora remains uncertain. However, all other features (arrangement of apertures, branches and kenozooecia) show high similarities with Bobiesipora fasciculata.

\section{"Heteropora similis Stoliczka, 1862" nomen dubium} (Fig. 1J)

Heteropora similis Stoliczka, 1862: 82, pl. 1, fig. 9.

Material EXAMINED. - Holotype of Heteropora similis, registered as 1859/0026/0138.

DiAGNOSIS. - Small fragments of columnar colony with oval transverse section. Zooecia of two types, the larger perhaps autozooecia, the smaller probably kenozooecia. No gonozooecium.

\section{REMARKS}

Owing to very poor preservation and the absence of a gonozooecium or any other characteristic features, the specimen is unrecognizable. The arrangement of apertures on the colony surface is cerioporine, somewhat comparable with Tetrocycloecia and/or Heteropora (see Zágoršek 2003, 2010).

\section{Suborder CANCELLATA Gregory, 1899 Family HORNERIDAE Gregory, 1899 Genus Hornera Lamouroux, 1821}

\section{Hornera cf. verrucosa Reuss, 1847}

(Fig. 2A)

?Hornera verrucosa Reuss, 1847 : 43, pl. 6, fig. 22; ?1851: 173, pl. 9, fig. 21 ; ?1866: 197, pl. 9, fig. 9.

\section{Hornera porosa Stoliczka, 1862: 79, pl. 1, fig. 3.}

Material eXAmined. - Two syntypes of Hornera porosa registered as $1862 / 0022 / 0048$. Owing to the lack of gonozooecia and unclear attribution of the species, no lectotype has been selected.

Diagnosis. - Apertures circular, alternating, forming more or less transverse rows. Cancelli of almost the same size, one proximal and one distal to the aperture. Dorsal side of colony with rare, scattered cancelli and anastomosing, wide, smooth nervi. Gonozooecia lacking in the Stoliczka specimens. 


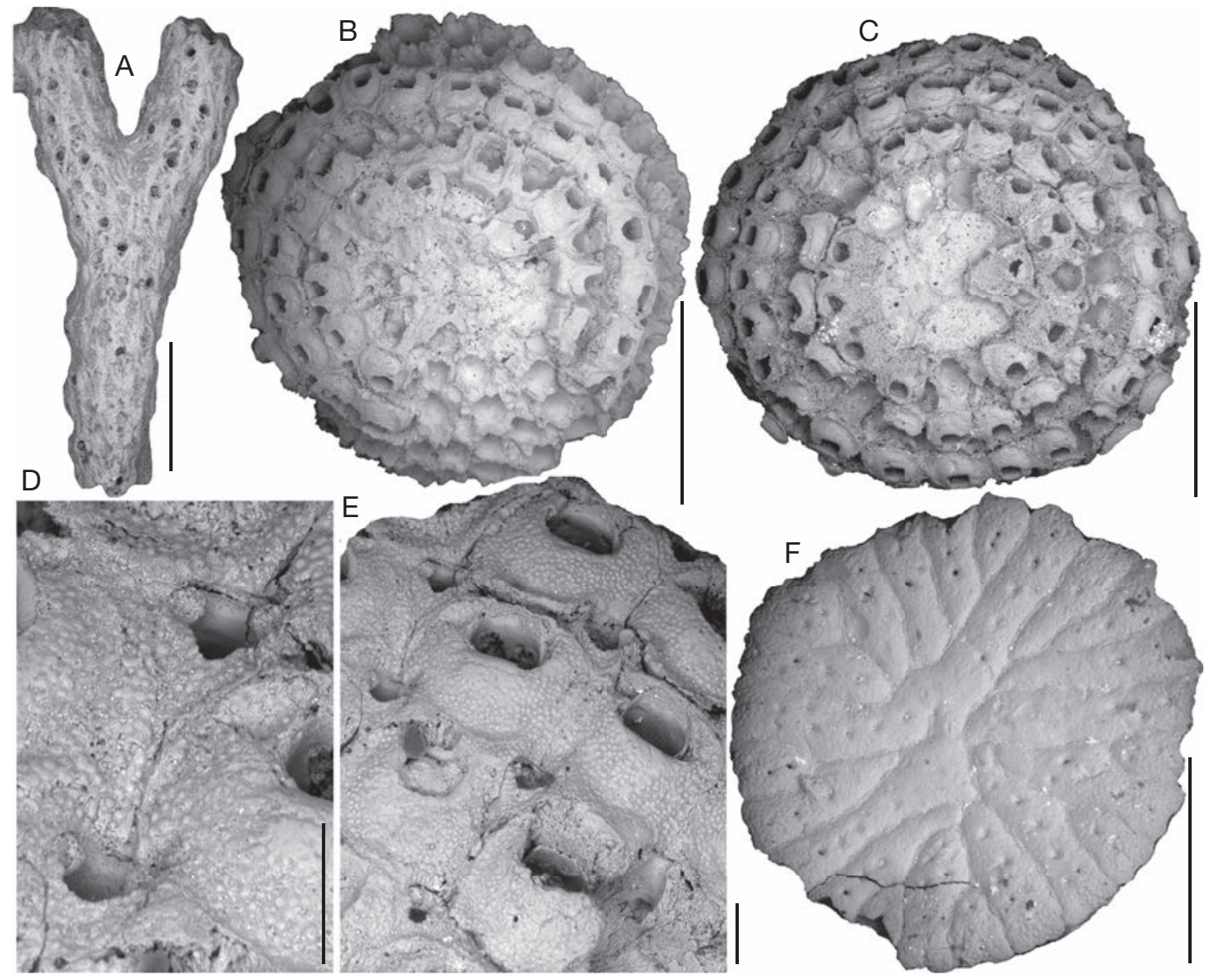

FIG. 2. - A, One of the syntypes of Hornera porosa identified as Hornera cf. verrucosa Reuss, 1847 due to the poor preservation and the lack of a gonozooecium; B-F, Lunulites latdorfensis Stoliczka, 1862; B, general view showing typical preservation, the central part sometimes revealing a preserved lithoclast; $\mathbf{C}$, lectotype showing arrangement of autozooecia; $\mathbf{D}$, vibracular zooecia, with triangular shape and distinct condyles; E, autozooecia showing granular cryptocyst and position of the vibracular zooecia; F, abfrontal (reverse) side of colony showing a single row of pores in each basal sector. Scale bars: A-C, F, 1 mm; D, E, $100 \mu \mathrm{m}$.

\section{REMARKS}

Owing to poor preservation and the lack of a gonozooecium, plus the unrecognisable type material of Reuss (1847), the species cannot be clearly identified. Moreover, Hornera verrucosa seems to represent an unresolved nomenclatural problem. Reuss (1847) described Hornera verrucosa as occurring in the Vienna Basin (Miocene). Reuss (1851) later described other specimens from the Miocene of Poland as Hornera verrucosa [but not sensu Reuss (1847)] and, moreover, further described Hornera verrucosa sensu Reuss (1851) from Söllingen (Oligocene). Reuss (1866) stated that the species occurred from Early through Late Oligocene and the Miocene, even though all these specimens may represent different species. Smith et al. (2008) synonymized these three descriptions as one species (sensu Reuss 1847). Resolving this problem requires a thorough revision of the whole concept of Neogene Hornera, which is beyond the scope of this paper.

Because of this imprecise determination of the species, Hornera verrucosa has subsequently often been reported from Neogene (e.g., Bobies 1958; Vávra 1977; Zágoršek 2010) as well as Eocene sediments (Zágoršek 2001, 2003). 
Suborder RECTANGULATA Waters, 1887

Family LICHENOPORIDAE Smitt, 1867

Genus Disporella Gray, 1848

"Disporella anhaltina (Stoliczka, 1862)"
nomen dubium

(Fig. 1K, L)

Pavotubigera anhaltina Stoliczka, 1862: 82, pl. 1, fig. 8.

Material eXamined. - Holotype of Pavotubigera anhaltina, registered as 1862/0022/0052.

DiagNoSis. - Small fragments of discoidal colony with autozooecia in radial fascicles. Fascicles comprising 1-2 parallel rows of apertures, slightly curving from centre of colony. Gonozooecium lacking.

\section{REMARKS}

The specimen is more or less unrecognizable owing to poor preservation and the absence of a gonozooecium. The arrangement of fascicles, however, resembles some species of Disporella (see Disporella radiata in Zágoršek [2003] and Disporella hispida in Zágoršek [2010]).

\section{Class GYMNOLAEMATA Allman, 1856}

Order CHEILOSTOMATA Busk, 1852

Suborder NEOCHEILOSTOMINA d'Hondt, 1985

Superfamily MicroporoideA Gray, 1848 Family LUNULITIDAE Gregory, 1893

Genus Lunulites Lamarck, 1816

\section{Lunulites latdorfensis Stoliczka, 1862} (Fig. 2B-F)

Lunulites Latdorfensis Stoliczka, 1862: 93, pl. 3, fig. 7. Reuss 1867: 232 (not found in the collection).

Material EXAMined. - Nine syntypes registered as 1867/0012/0018; five of them belong to Lunulites latdorfensis. A lectotype (Fig. 2C; designated here) has been selected from them that corresponds closely with Stoliczka (1862: pl. 3, fig. 7). The other four specimens belong to different species of Lunulites.

DiAGNOSIS. - Colony small, discoidal, always preserved intact. Autozooecia in very regular concentric rows, about 4-5 per colony. No budding from the fragments observed. Autozooecia roundly rectangular with granular frontal wall. Orifice semicircular. Vibracula small, acutely triangular. Dorsal side comprising sectors as wide as an autozooecium and arranged more or less radially, slightly chaotically curved. Only one row of pores per sector.

\section{REMARKS}

The most characteristic features are: small colonies with very regularly arranged concentric rows of autozooecia, small triangular vibracula and one row of pores per sector.

Family ONYCHOCELLIDAE Jullien, 1881

Genus Onychocella Jullien, 1882

Onychocella subpyriformis (d'Archiac, 1846)

Eschara subpyriformis d'Archiac, 1846: 195.

Membranipora (Semiflustrella) anhaltina Stoliczka, 1862: 85, pl. 2, fig. 4.

Onychocella subpyriformis - Zágoršek 2003: 139, pl. 14, fig. 2 (cum syn.).

Material eXamined. - Holotype of Membranipora (Semiffustrella) anhaltina, registered as 1862/0022/0054.

DiAGNOSIs. - Colony erect, multiserial, with flat cross section. Autozooecia hexagonal to oval, slightly longer than wide with large, semilunar opesia. Cryptocyst extensive, shallow, flat and smooth. Vicarious avicularium as long as but half as wide as autozooecium; orifice of vicarious avicularium small, circular, or seldom narrow and oval; rostrum very long, acute distally and usually curved laterally.

\section{REMARKS}

The Stoliczka specimen is identical with the material described by Braga (1980) and Zágoršek (2001, 2003) as Onychocella subpyriformis (d'Archiac, 1846). As Braga (1980) pointed out, O. subpyriformis is quite variable and one of the commonest Eocene species in the Alpine Carpathians region.

\section{Family STEGINOPORELLIDAE Hincks, 1884 Genus Steginoporella Smitt, 1873}

\section{Steginoporella cf. reingruberhohensis Zágoršek, 2003} (Fig. 3A)

?Steginoporella reingruberhohensis Zágoršek, 2003: 142, pl. 15, figs 3,4 . 


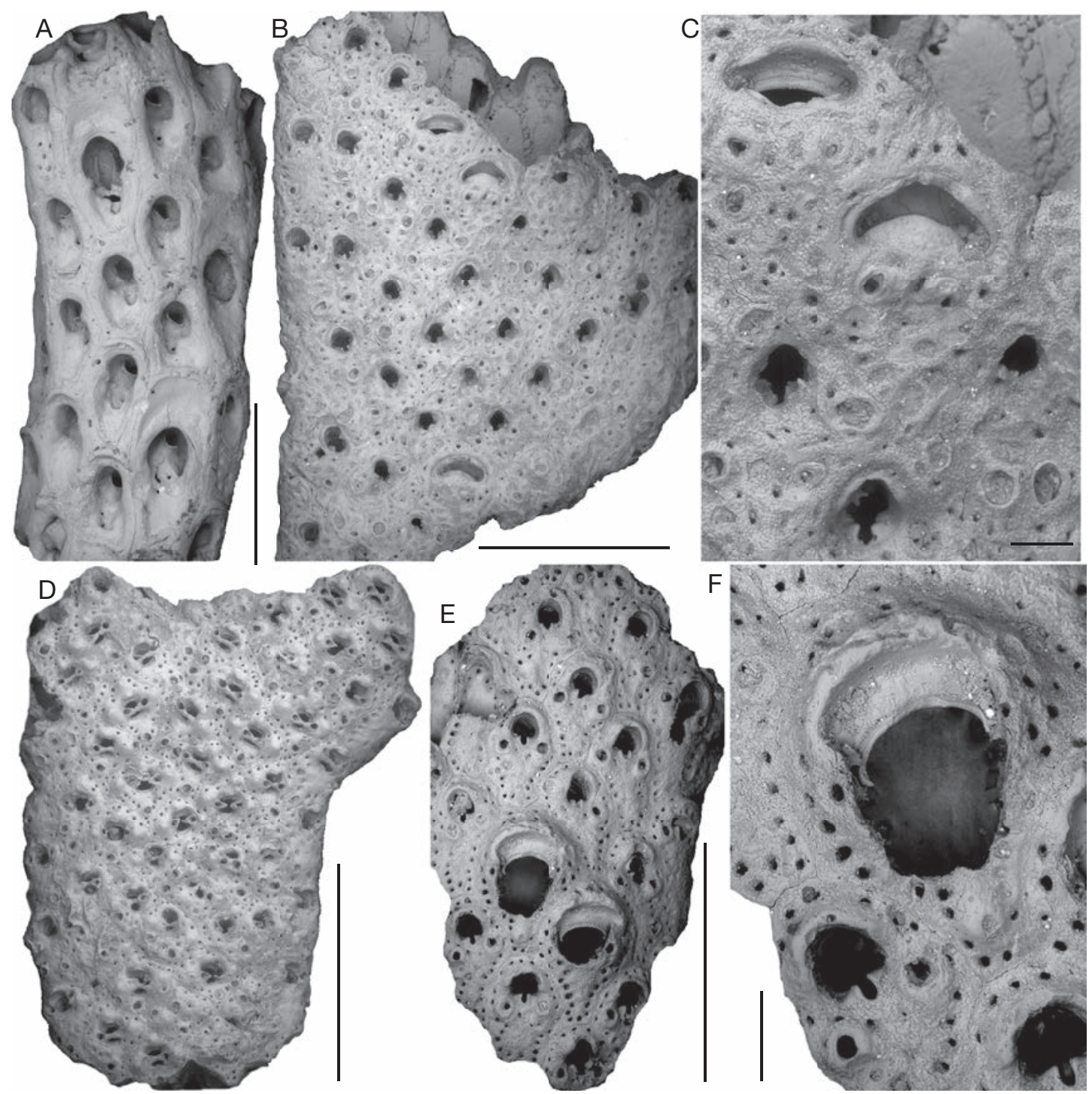

FIG. 3. - A, Lectotype of Eschara reussi identified as Steginoporella cf. reingruberhohensis Zágoršek, 2003 showing large avicularia (top and lower right) and elevated distal zooecial rims; B-D, Adeonella ornatissima (Stoliczka, 1862); B, general view of lectotype with autozooecia and maternal zooecia; C, maternal zooecia showing the characteristic semilunar aperture and autozooecia with a deep narrow sinus; D, lectotype designated here as older stage of colony development showing secondary calcification producing a transverse apertural bar; E, F, Adeonella mortisaga (Stoliczka, 1862), n. comb.; E, general view of lectotype showing autozooecia with two suboral avicularia and large maternal zooecia; F, maternal zooecium with very large aperture (partly broken) and autozooecia with a narrow sinus. Scale bars: A, B, D, E, $1 \mathrm{~mm} ; \mathrm{C}, \mathrm{F}, 100 \mu \mathrm{m}$.

Non Cellaria haidingeri Reuss, 1848: 60, pl. 7, fig. 30.

Eschara reussi Stoliczka, 1862: 88.

Non Steginoporella cucullata Pouyet \& David, 1979: 774, fig. 3, pl. 3, fig. 10 (cum syn.).
MATERIAL EXAMINED. - Two syntypes of Eschara reussi registered as 1859/0026/0136. The chosen lectotype (designated here) is illustrated in Fig. 3A.

DiaGNOSIS. - Colony erect, columnar, multiserial, large with oval to circular transverse section. Autozooecia oval 
to hexagonal, arranged in nine regular longitudinal rows. Mural rim wide and smooth. Cryptocyst shallow, perforated by 7-12 large pores but lacking opesiules. Orifice sunken, subcircular in shape, situated on the end of short peristome, bordered by a thin low rim. The vicarious avicularia (Bzooecia) up to twice as long and wide as autozooecia, with broad, truncate distal margin; cryptocyst perforated by about ten pores; palate wider than long, smooth, shallowly concave. Owing to poor preservation, opesial characters of vicarious avicularia are somewhat equivocal but polypide tube is well developed, its orifice similar to that of autozooecia.

\section{REMARKS}

Zágoršek (2003) synonymised this species with Steginoporella haidingeri (sensu Reuss 1848). SEM study of Stoliczka's material, however, shows features more reminiscent of Steginoporella reingruberhohensis Zágoršek, 2003. The main difference is the number of cryptocystal perforations. Whereas $S$. haidingeri usually has about $20-30$ pores, $S$. reingruberhohensis has about 10-15, which is closer to the number (712) in Eschara reussi. Owing to the unclear cryptocystal features of the vicarious avicularia, these two species cannot presently be synonymised and the status of Eschara reussi remains unclear.

David \& Pouyet (1974) and Pouyet \& David (1979) synonymised Eschara reussi Stoliczka, 1862 with Steginoporella cucullata (Reuss, 1848). As already discussed by Zágoršek (2003), S. cucullata has a very wide mural rim, a consistently preserved pair of circular opesiules, and a wide vicarious avicularian palate. It is, moreover, a Miocene species.

\section{Superfamily ADEONOIDEA Busk, 1884 \\ Family ADEONIDAE Busk, 1884 Genus Adeonella Busk, 1884}

\section{Adeonella ornatissima (Stoliczka, 1862)}

(Fig. 3B-D)

Eschara (Escharifora) ornatissima Stoliczka, 1862: 86, pl. 2, fig. 7 .

Adeonella ornatissima - Zágoršek 2003: 152, pl. 19, fig. 2 (cum syn.).

MATERIAL EXAMINED. - Two syntypes registered as 2010/0259/0010. The chosen lectotype (designated here) corresponds with Stoliczka's illustration (1862: pl. 2, fig. 7) and is depicted in Figure 3D herein.
DiagnOSIS. - Colony erect, flat, multiserial, bifurcating, with 8-10 longitudinal rows of autozooecia. Autozooecia at colony margin can be more than twice as long as those in colony centre. Frontal shield without granulations, knobbly, perforated by marginal areolar pores; lateral tubercles sometimes developing when secondary calcification occurs; frontal area relatively narrow in zooecia located in middle part of colony. Orifice oval to suborbicular with broad poster. Lateral-oral pair of avicularia small, circular, often fusing as bridge across aperture in older parts of colony. Secondary calcification often expressed as well-developed tubercles situated usually in corners of zooecia.

\section{REMARKS}

Adeonella ornatissima differs from Adeonella mortisaga (Stoliczka, 1862), n. comb. in having shorter autozooecia with a knobbly frontal shield and oral avicularia that may fuse across the aperture.

Adeonella mortisaga (Stoliczka, 1862), n. comb. (Fig. 3E-F)

Eschara (Escharifora) mortisaga Stoliczka, 1862: 86, pl. 2, fig. 6.

Material EXAmined. - Two syntypes registered as 1859/0026/0137. The chosen lectotype (designated here) corresponds with Stoliczka's illustration (1862: pl. 2, fig. 6) and is depicted as Figure 3E herein.

DiAGNOSIS. - Colony erect, multiserial. Autozooecia may be rhomboidal in central part of colony, more elongate on colony margin. Frontal shield granular, perforated by marginal areolar-septular pores. Orifice with transversely $\mathrm{D}$-shaped anter and narrow sinus. Adventitious avicularia small, paired, one on either side suborally. Maternal zooecia up to more than twice as wide distally as autozooecia, with smooth ooecial margin much wider than long, showing beneath distal secondary calcification. Secondary zooecial calcification often accompanied by tubercles situated usually in margins and/or on frontal shield including loci of suboral avicularia.

\section{REMARKS}

This species differs from $A$. ornatissima in having very large maternal zooecia, longer autozooecia with granular frontal shields, and suboral (not lateral-oral) avicularia. It is similar also to Adeonella minor (Reuss, 1869) which, however, never has such large brooding zooids and the apertural sinus is less prominent. 


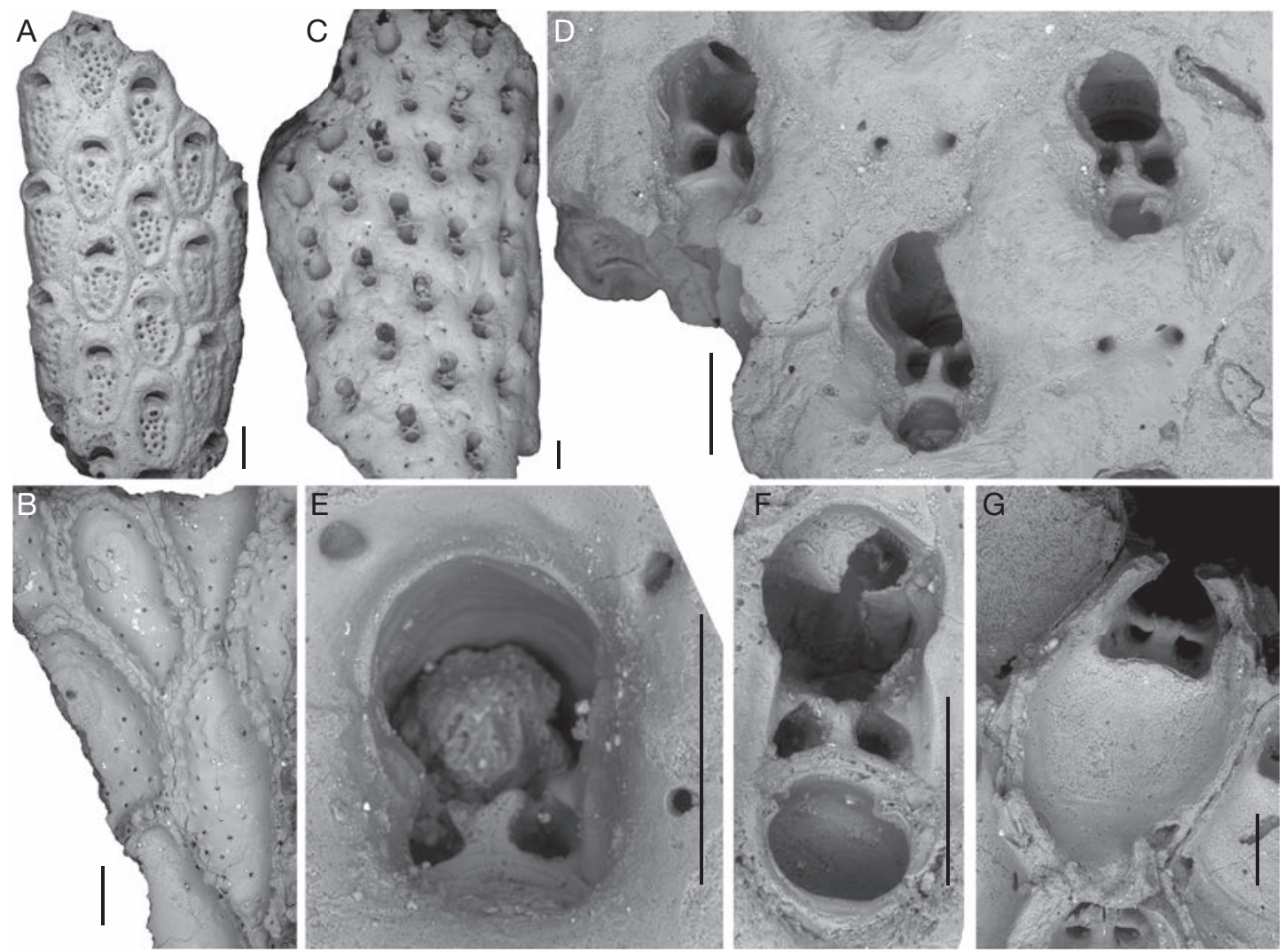

FIG. 4. - A, Adeonellopsis pulchra (Stoliczka, 1862) n. comb., lectotype showing arrangement of autozooecia; B, interior view of holotype of Lepralia pedicularis showing elongate zooecial chambers with mixed frontal shields and scattered lepralioid pseudopores; due to the very poor preservation and the absence any other characteristic features described here as "Lepralia pedicularis Stoliczka, 1862" nomen dubium; C-G, Stoliczkella subovata (Stoliczka, 1862) n. comb.; C, general view of lectotype; D, detail of three autozooecia showing deeply immersed apertures and a proximal pair of frontal areolar pores; E, autozooecial aperture showing a Y-shaped denticle; F, autozooecial aperture showing spiraminal openings produced by fusion of lateral processes, proximal to which is a suboral avicularium; G, interior of the autozooecium showing umbonuloid surface and primary aperture with slightly convex proximal margin. Scale bars: $100 \mu \mathrm{m}$.

Genus Adeonellopsis MacGillivray, 1886

Adeonellopsis pulchra (Stoliczka, 1862) n. comb. (Fig. 4A)

Eschara (Porellia) pulchra Stoliczka, 1862: 87, pl. 2, fig. 10.

Material EXAMineD. - Three syntypes registered as 1862/0022/0056. The chosen lectotype (designated here) corresponds with Stoliczka's illustration (1862: pl. 2, fig. 10) and is depicted as Figure 4A herein.

DiAGNOSIS. - Colony columnar, multiserial with 6-8 autozooecial rows. Autozooecia elongate-oval with thick raised margins and very small areolar-septular pores in interzooidal furrows. Frontal shield mostly occupied by a very large spiraminal area with 12-16 perforations. Aperture semilunar to semicircular, narrow. Avicularia mostly median suboral, more or less transversely orientated with a very short acute rostrum; mostly eroded and represented by a subcircular foramen, this only slightly larger than spiraminal pores in some zooecia. Gonozooecium unknown.

\section{REMARKS}

Adeonellopsis pulchra n. comb. differs from other similar species in having a small avicularium and a large spiraminal area, perforated by more than 12 pores (Fig. 4A), that leaves a very narrow remaining area of frontal shield that comprises a raised rim. 


\section{“Lepralia pedicularis Stoliczka, 1862" nomen dubium}

(Fig. 4B)

Lepralia pedicularis Stoliczka, 1862: 84, pl. 2, fig. 2.

MATERIAL EXAMINED. - Holotype of Lepralia pedicularis, registered as 1862/0022/0053.

\section{DESCRIPTION}

Colony robust, erect, bifurcating, exteriorly heavily secondarily calcified and rather densely perforated by tiny pores, some of which are in linear series. Obvious autozooecial boundaries are lacking although very thin, faint lines may be indicative; no other exterior features are visible. Interior view of a fracture shows parts of several elongate zooecial chambers with undersides of mixed frontal shields excluding orifices; each shows the internal openings of sparsely scattered lepralioid pseudopores and a small oval umbonuloid area of planar-spherulitic microstructure, bounded by a ring scar and in the centre of which is a foramen. Interzooecial communications via simple, uniporous pore.

\section{REMARKS}

The internal opening surrounded by a small umbonuloid area of exterior skeletal wall is highly distinctive. The only other known example at the present time is a species of Siphonicytara (Gordon \& Taylor in press), from the Early Eocene of Chatham Island, New Zealand, which has an identical arrangement. Insofar as all other examined species of Siphonicytara Busk, 1884 have an ascopore, Gordon \& Taylor interpreted the foramen as technically a spiraminal opening and that the genus evolved from a fully umbonuloid ancestor, perhaps resembling Beisselina Canu, 1913.

Lepralia pedicularis need not have belonged to a family Siphonicytaridae, however. Members of this monogeneric family were rooted in soft sediments and no known species has the same degree of robust secondary calcification. Adeonidae is a much more likely family, members of which include wholly umbonuloid and wholly lepralioid frontal shields; no species has yet been found with a skeletally mixed shield but it is highly likely that such species exist. Based on external appearance, similar colonies are produced by several genera in Miocene of the Paratethys. The most similar is the non-spiraminate adeonid Schizostomella grinzingensis David \& Pouyet, 1974, the branches of which are often heavily calcified proximally, gradually obliterating apertures and just leaving scattered pores and thin zooecial boundary lines as in L. pedicularis. Similarly, spiraminate fossil Reptadeonella cf. violacea (Johnston, 1847), as described by Zágoršek (2010), also produced heavily calcified parts of multilamellar colonies in which some orifices and spiramina become almost completely obliterated. Species of Reptadeonella, however, are all encrusting. Our conclusion is that Lepralia pedicularis is a presently indeterminable genus of adeonid and the species is nomen dubium.

Superfamily LEPRALIELLOIDEA Vigneaux, 1949

Family BRYOCRYPTELLIDAE Vigneaux, 1949

$$
\text { Genus Stoliczkella n. gen. }
$$

TYPE SPECIES. - Eschara (Flustrina) subovata Stoliczka, 1862.

Eтyмology. - Honorific for Ferdinand Stoliczka (Czech, Stolička), 7 June 1838-19 June 1874, a Moravian paleontologist who worked in India on paleontology, geology and various aspects of zoology, including ornithology and herpetology. He died of high-altitude sickness, at the early age of 36 , during an expedition across the Himalayas.

DiagNosis. - Erect, bilamellar colonies with median lamina and narrow, flat or with lensoidal cross section. Autozooecia umbonuloid, frontally imperforate apart from marginal areolar-septular pores. Aperture with median and lateral processes forming paired peristomial spiramina. Large suboral avicularia and imperforate immersed ooecium. Additional adventitious and vicarious avicularia may be present, the latter larger than autozooecia and situated along the colony margin.

\section{REMARKS}

The apertural features of Stoliczkella n. gen. superficially resemble some species of the genus Galeopsis Jullien \& Calvet, 1903 (Celleporidae), in which paired lateral-oral avicularia can fuse across the aperture forming a bridge and peristomial spiramen. In Stoliczkella n. gen., a median process fuses with a pair of lateral processes to form a double 
spiramen and the apertural avicularium is single and median-suboral. Further, the frontal shield is umbonuloid with a distinct ring scar surrounding an area of planar-spherulitic ultrastructure on the undersurface, whereas the frontal shield in Galeopsis is lepralioid-cryptocystidean.

The double apertural spiramen resembles similar arrangements in some species of Exochella Jullien, 1888 (Romancheinidae), but the median suboral avicularium and erect habit suggest Bryocryptellidae. It may be that these two families (Romancheinidae Jullien, 1888 and Bryocryptellidae Vigneaux, 1949) should be merged but the type species of the type genera do not suggest a close relationship. Stoliczkella n. gen. is introduced here for two species described by Stoliczka (1862).

Stoliczkella subovata (Stoliczka, 1862) n. comb. (Fig. 4C-G)

Eschara (Flustrina) subovata Stoliczka, 1862: 87, pl. 2, fig. 9.

Non Reteporella subovata - Zágoršek 2001: 558, pl. 20, fig. 2; 2003: 181, pl. 31, fig. 5 .

Galeopsis cf. subquadrangularis - Zágoršek 2001: 556, pl. 19, fig. 1; 2003: 179, pl. 29, figs 3, 4 .

Material EXAMINED. - Seven specimens labelled as Eschara (Flustrina) subovata registered as 2010/0259/0006, but only five may be regarded as syntypes. Two specimens belong to the genus Reteporella. The chosen lectotype (designated here) corresponds with Stoliczka's illustration (1862: pl. 2, fig. 9) and is depicted as Figure 4B herein.

\section{DESCRIPTION}

Colony erect, bilamellar, flat or with lensoidal cross section, with zooecial orientation indicative of potential bifurcation distally, autozooecia opening on both faces. Autozooecia somewhat elongateoval (especially in interior view) to rhomboidal, although exterior boundary lines can disappear with secondary calcification. Frontal shield umbonuloid, frontally smooth, convex, imperforate except for tiny marginal areolar pores, these often tending to be lacking laterally, paired proximally. Interior view shows a large area of planar-spherulitic microstructure bordered by a ring scar. Peristomial aperture shows a proximal median process that may or may not have $2-3$ slight projections distally; median process fusing with a projection from either side to form a pair of spiramina; this arrangement more clearly seen from interior view, with the median process sometimes grooved. 'Primary orifice' (observable from interior view) semicircular with slightly convex proximal margin. Oral spines absent. Median suboral avicularium relatively large, subcircular, rostrum proximofrontally directed, crossbar mostly broken. Ooecium deeply immersed, recumbent on distal zooecium, ectooecium imperforate, typically somewhat concealed by secondary calcification. Additional smaller adventitious avicularia, circular, sparsely found laterofrontally or proximally on frontal shield, with rostrum directed obliquely laterally or proximally. Vicarious avicularia situated on margin of the colony, these larger than autozooecia with a rounded rostrum and oval aperture.

\section{REMARKS}

Two species occurred in a single box with the same name (Eschara (Flustrina) subovata) and registration number. Five specimens are Stoliczkella subovata n. comb. and correspond with Stoliczka's original description and illustrations. The remaining two specimens belong to Reteporella and comprise colony fragments with apertures opening only on one side. These two specimens were erroneously cited as Eschara (Flustrina) subovata by Zágoršek (2001, 2003) and listed under Reteporella. According to Stoliczka's original description and illustration, Eschara (Flustrina) subovata has bilamellar colonies (with a medial lamella) that definitely do not belong to Phidoloporidae; the species described as Reteporella subovata from Eocene sediments of Reingruberhohe (Zágoršek 2003) and Buda Marls (Zágoršek 2001) may represent a new species of Reteporella.

The specimen described by Zágoršek (2003) as Galeopsis cf. subquadrangularis (Reuss) corresponds to Stoliczkella subovata n. comb. in having elongateoval autozooecia, large suboral avicularia and one pair of areolar septular pores in the proximal part of the autozooecium. Although adventitious and vicarious avicularia have not been observed in the Reingruberhohe specimens, we believe they belong to Stoliczkella subovata n. comb. 
Stoliczkella crenatula (Stoliczka, 1862) n. comb. (Fig. 5A-F)

Eschara crenatula Stoliczka, 1862: 87, pl. 2, fig. 8.

Material eXAmined. - Five syntypes, registered as 2010/0259/0007. Stoliczka's (1862) illustration does not correspond exactly to any of the specimens labelled as Eschara crenatula, hence the illustrated specimen may be lost, or Stoliczka inadvertently illustrated a different species. The selected lectotype (designated here) is the best-preserved of the syntypes and is depicted as Figure 5A herein.

\section{DESCRIPTION}

Colony erect, bilamellar, flat, autozooecia opening on both faces. Autozooecia of similar shape to S. subovata n. comb., with combined peristomial aperture/suboral avicularium complex proportionately larger, occupying a considerable part of frontal surface. Frontal shield smooth, imperforate except for small, sparse, areolar-septular pores in the margins typically paired proximally. Secondary calcification increases convexity of frontal shield. Two areolar-septular pores situated on the proximal margin of the autozooecia, sometimes indistinct. 'Primary aperture' deeply immersed beneath peristomial aperture, the rim of which embraces the suboral avicularium so that the paired spiramina and broken avicularian chamber often appear as three holes of equivalent size. Median process separating spiramina shorter than in S. subovata n. comb. Oral spines absent. Suboral avicularium circular, with no trace of crossbar remaining in any zooecium. Ooecium deeply immersed, recumbent on distal zooecium, ectooecium imperforate, typically mostly concealed by secondary calcification. Adventitious avicularia rare on frontal shield, large, with long rostrum tapering laterally. Vicarious avicularia situated on the margin of colony, as large as autozooecium, with rounder rostrum and drop-like aperture.

\section{REMARKS}

The type material examined cannot be fractured and the interior of the frontal shield and aperture have not been observed. From frontal view we infer that the construction of the spiraminal complex is similar to that in S. subovata n. comb. Stoliczkella crenatula n. comb. differs from S. subovata n. comb. in having shorter autozooecia, smaller suboral avicularia and larger adventitious avicularia with a pointed rostrum.

\section{Family EXECHONELLIDAE Harmer, 1957 \\ Genus Anarthropora Smitt, 1868}

\section{Anarthropora macropora \\ (Stoliczka, 1862) n. comb.}

(Fig. 6A-D)

\section{Lepralia macropora Stoliczka, 1862: 84, pl. 2, fig. 3.}

Adeona sp. n. - Nehyba et al. 2008: 55, table 3.

Material EXAmined. - Three syntypes, registered as 1859/0026/0140. The selected lectotype (designated here) corresponds with Stoliczka's illustration (1862: pl. 2, fig. 3) and is depicted as Figure 6A herein.

Diagnosis. - Colony encrusting, autozooecia suboval, arranged in irregular longitudinal rows. Frontal shield coarsely perforated by 8-12 large excavations, each bowl-shaped with a broad smooth rim and the sides sloping to a smaller hole edged with several blunt denticles, these conferring a stellate appearance to each foramen. Peristomial aperture subcircular to transversely oval, with low rim; deeper interior proximal margin of aperture straight with tiny separated denticles along its edge. No oral spines. Small avicularian chamber on mid-distal rim of peristome; a larger avicularium situated suborally at one corner of the aperture, the rostrum long, acute, directed laterally, no crossbar or pivots. No ooecia observed.

\section{REMARKS}

Recent Anarthropora monodon Busk, 1860 (type species) differs in having a much more densely foraminate frontal shield and smaller peristomial avicularia.

Family ROMANCHEINIDAE Jullien, 1888 Genus Escharella Gray, 1848

Escharella grotriani (Stoliczka, 1862) (Fig. 6E-F)

Lepralia grotriani Stoliczka, 1862: 84, pl. 2, fig. 1. 

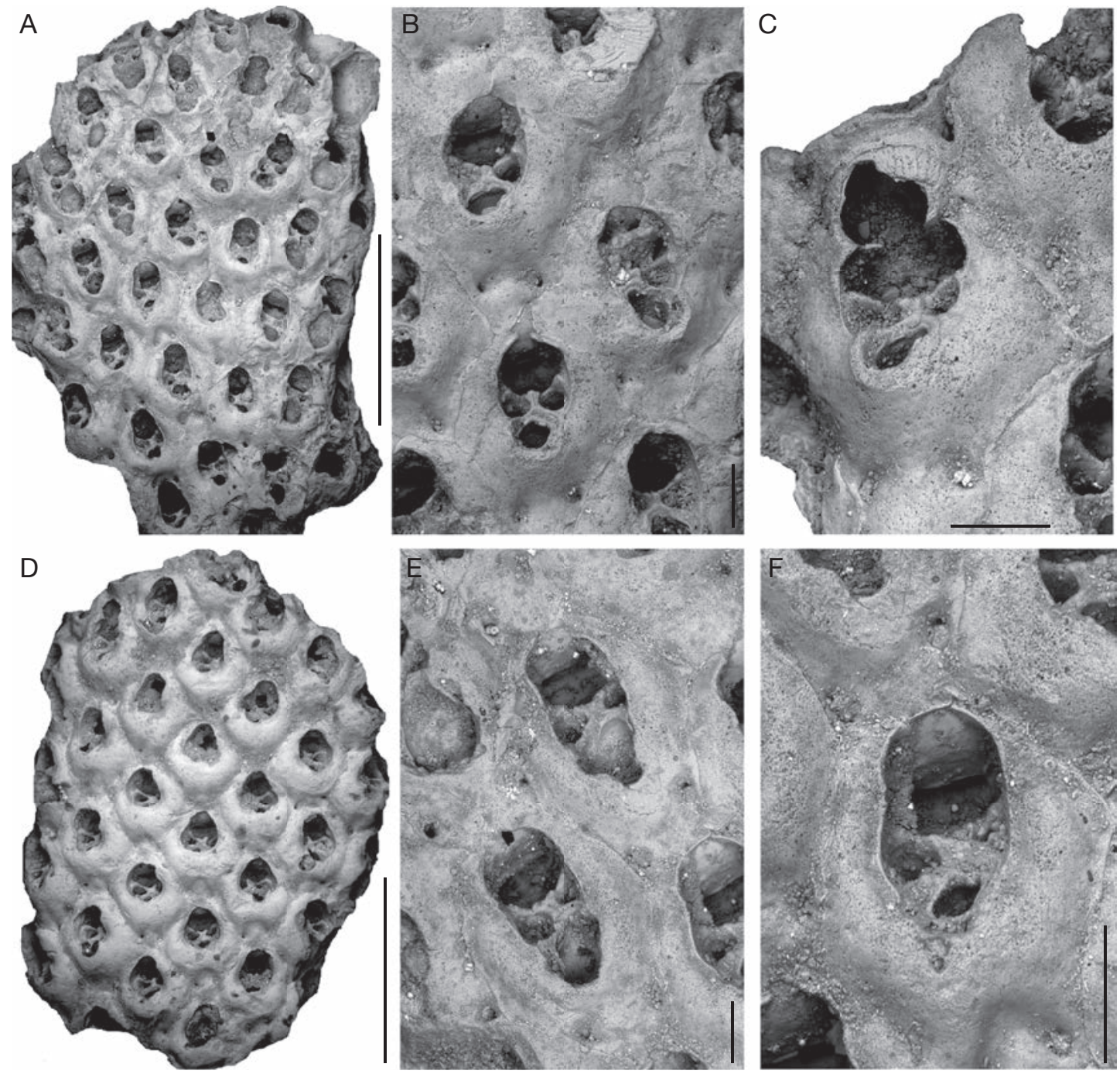

FIG. 5. - Stoliczkella crenatula (Stoliczka, 1862), n. comb.; A, general view of lectotype; B, autozooecial apertures with suboral avicularia smaller than those in Stoliczkella subovata n. comb. (cf. Fig. 3F); C, partly preserved ooecium; D, older stage of colony development showing secondary calcification; E, autozooecia with deeply immersed ooecia and small avicularia; $\mathbf{F}$, autozooecial aperture with proximal depression accommodating areolar pores. Scale bars: A, D, $1 \mathrm{~mm}$; B, C, E, F, $100 \mu \mathrm{m}$.

Escharella grotriani - Zágoršek 2001: 51, pl. 17, fig. 8; 2003: 157 (cum syn.).

Material examined. - Holotype, registered as $1862 / 0022 / 0051$.

DiAGNOSIS. - Colony encrusting, the fragment comprising three short rows of autozooecia, these rhomboidal to oval with about 30 very small marginal areolar-septular pores. Frontal shield prominent, convex, smooth or slightly granular, with a small umbo. Aperture oval with a shallow lyrula and usually 5-7 oral-spine bases around periphery. Ooecium small, globular, recumbent on distal zooecium; ooecial aperture not preserved.

\section{REMARKS}

Escharella grotriani differs from Escharella tenera (Reuss, 1874) in having a small umbo on the frontal shield, 5-7 oral spines and broad, rhomboidal 
autozooecia. Zágoršek (2003) presented a detailed discussion of the generic attribution of this species.

Superfamily SCHIZOPORELLOIDEA Jullien, 1883

Family MYRIAPORIDAE Gray, 1841

Genus Myriapora De Blainville, 1830

Myriapora? beyrichi (Stoliczka, 1862) n. comb. (Fig. 6G-H)

Cellaria beyrichi Stoliczka, 1862: 83, pl. 1, fig. 10.

Material eXamined. - Holotype, registered as 1859/0026/0133.

DiAgNosis. - Colony multiserial, erect with circular cross section. Branch fragment comprising fewer than 20 autozooecia, these trapezoidal, with densely pseudoporous frontal shields bordered by smooth interzooidal boundaries that represent frontally eroded adjacent zooecial margins. Apertures large, more or less cleithridiate with wedge-shaped sinus delimited by prominent condyles. No avicularia or ooecia.

\section{REMARKS}

The smooth interzooecial boundaries and cleithridiate orifice are distinctive features of this species. The generic attribution is uncertain in the absence of ovicells and avicularia. The apertural shape most resembles that seen in Myriapora, a genus confined to Mediterranean and Arctic-Boreal waters, whose species, however, do not normally have such distinct interzooecial boundaries. A species with similarlooking zooecia is Myriapora kuhni Vávra, 2011, from the Oligocene of Germany; it is encrusting, however, and the visible autozooecial boundaries do not form such a wide outline.

On the other hand, the colonial and zooecial morphology of Stoliczka's species match that found in Opphiphorina Gordon \& d'Hondt, 1997 (Phorioppniidae), a monotypic genus known only from New Caledonia and the Kermadec Islands in the Southwest Pacific. Oppiphorina epaxia (Gordon, 1984) has somewhat cleidridiate apertures (with a broader sinus, however) and densely perforated zooecia with raised margins that, if eroded, would present exactly the smooth interzooecial boundaries seen in $C$. beyrichi. Similar margins are seen in confamilial Phorioppnia Gordon \& d'Hondt,
1997 from New Caledonia, which, however, has non-cleithridiate apertures and dimorphic female orifices. Only the finding of ovicells in Stoliczka's species will settle the matter.

Family MARGARETTIDAE Harmer, 1957

Genus Tubucella Canu \& Bassler, 1917

Tubucella mammillaris

(Milne Edwards, 1836)

(Fig. 6I, J)

Eschara mammillaris Milne Edwards, 1836: 336, pl. 11, fig. 10.

Eschara (Porina) porulosa Stoliczka, 1862: 89, pl. 3, fig. 3.

Tubucella mammillaris - Zágoršek 2001: 67, pl. 28, figs 2, 3, 5; 2003: 176 (cum syn.).

MATERIAL EXAMINED. - Three syntypes of Eschara porulosa, registered as 2010/0259/0009. The chosen lectotype (designated here) corresponds with Stoliczka's illustration (1862: pl. 3, fig. 3) and is depicted as Figure 6I herein.

Diagnosis. - Colony large, bilamellar, with lensoidal cross section and well-developed median lamella. Autozooecia hexagonal to circular, arranged in c. 12-15 longitudinal series around branch. Each autozooecium comprising two regions of about equal length, a distal peristomial part and a proximofrontal part, the former strongly convex, sometimes hexagonal, the latter weakly convex, not clearly delimited from that neighbours, the frontal shield coarsely pseudoporous. Aperture circular to oval, surrounded by thick, low peristome. Ascopore of similar size to pseudopores, situated in distal half of autozooecia. Ooecia and avicularia lacking.

\section{REMARKS}

The separation of autozooecia into two parts as described by Zágoršek (2003) and also illustrated by Bock (2013a) is not evident in the syntype specimens (the thin threads of calcification normally separating these parts are not observable). Other features, however (flat colonies, presence of median lamella and ascopore situated in the distal half of the autozooecium), clearly identify this species.

Tubucella mammillaris differs from Tubucella papillosa (Reuss, 1848) in having flatter branch profiles (T. papillosa has more-rounded branches), shorter autozooecia (more elongate in T. papil- 

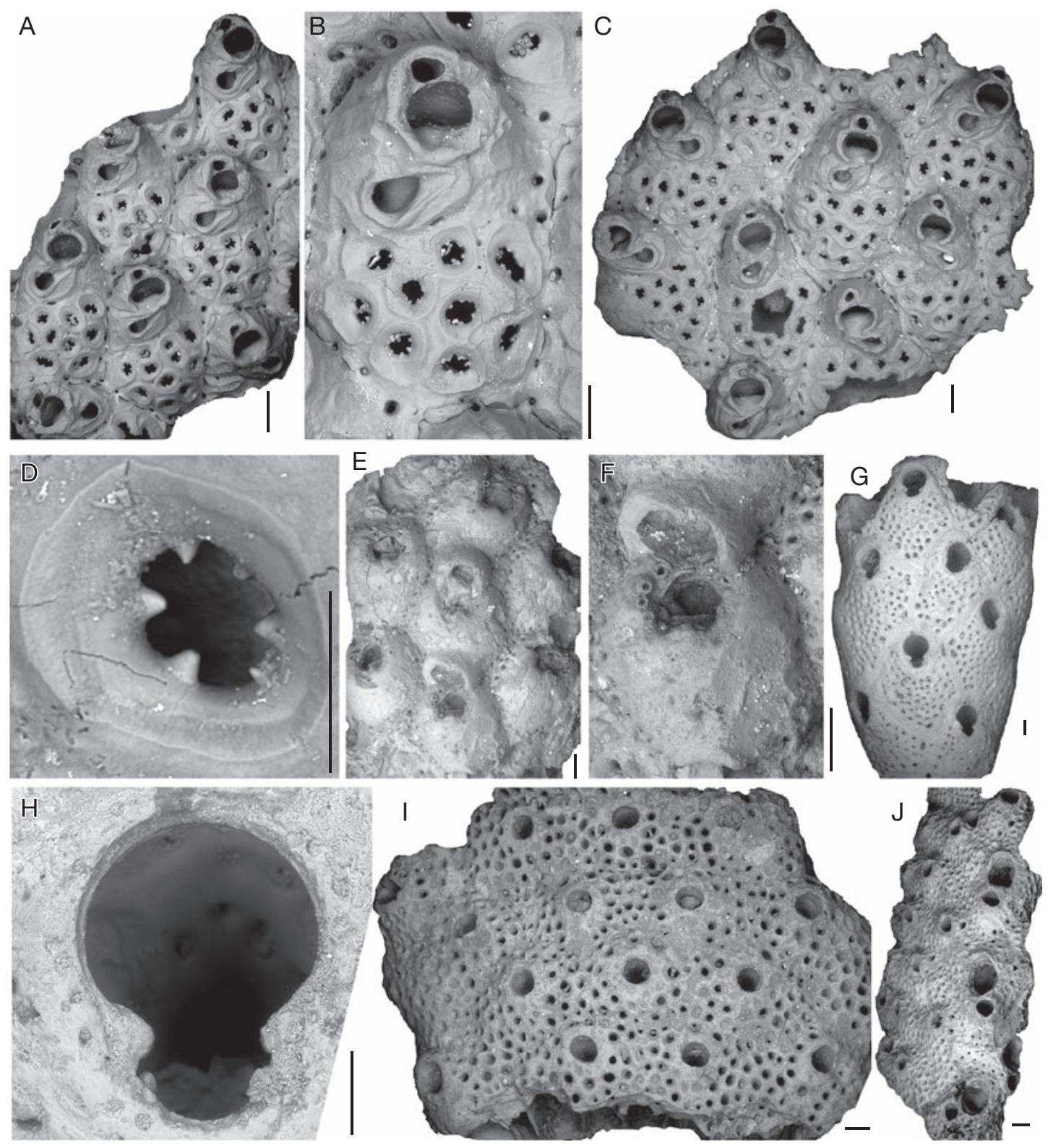

FIG. 6. - A-D, Anarthropora macropora (Stoliczka, 1862), n. comb.; A, general view of lectotype; B, autozooecium showing frontal foramina and suboral avicularium; C, syntype showing quincuncial arrangement of autozooecia; D, frontal-shield foramen showing well-preserved radial denticulation; E, F, Escharella grotriani (Stoliczka, 1862); E, lectotype showing arrangement of autozooecia; F, zooecium with ooecium and oral spines; G, H, Myriapora? beyrichi (Stoliczka, 1862), n. comb.; G, lectotype showing smooth outlines of autozooecia; $\mathbf{H}$, detail of aperture with condyles typical of myriaporids; I, J, syntype of Eschara porulosa identified as Tubucella mammillaris (Milne Edwards, 1836); I, general view of chosen lectotype of synonymous Eschara porulosa Stoliczka, 1862; J, lateral view of colony showing autozooecia with large apertures. Scale bars: $100 \mu \mathrm{m}$. 
losa) and the ascopore situated closer to the aperture (near the centre of the frontal shield in T. papillosa).

Superfamily Celleporoidea Johnston, 1838 Family Phidoloporidae Gabb \& Horn, 1862

\author{
"Retepora fasciata Stoliczka, 1862" \\ nomen dubium
}

Retepora fasciata Stoliczka, 1862: 91, pl. 3, fig. 4.

Material eXamined. - Holotype of Retepora fasciata, registered as 1862/0022/0044.

DiAGNOSIS. - Poorly preserved small fragment of branch with zooecia arranged in two longitudinal rows on one side only. Autozooecia elongate, lacking clear boundaries. Apertural characters weakly defined, possibly including a suboral spiramen or broken avicularian chamber. No frontal avicularia or ooecia observed.

\section{REMARKS}

Owing to the very poor preservation of the specimen, with weakly defined autozooecia and no obvious avicularia and ovicells, this species must be regarded as a nomen dubium.

Superfamily CONESCHARELLINOIDEA Levinsen, 1909

Family Orbituliporidae Canu \& Bassler, 1923 Genus Orbitulipora Stoliczka, 1862

\section{Orbitulipora haidingeri Stoliczka, 1862} (Fig. 7A-H)

Orbitulipora haidingeri Stoliczka, 1862: 91, pl. 3, fig. 5.

Non Orbitulipora petiolus Lonsdale, 1850: 151. —Cheetham 1966: 105, fig. 80.

?Orbitulipora petiolus - Bassler 1953: p. G230, fig. 172.1.

Orbitulipora petiolus - Braga \& Barbin 1988: 530. Zágoršek 2003: 184, pl. 31, fig. 6 (cum syn.).

MATERIAL EXAMINED. - Five syntypes, registered as 1862/0022/0045. The chosen lectotype (designated here) corresponds with Stoliczka's illustration (1862: pl. 3, fig. 5) and is depicted as Figure 7A herein. The Auversian specimen illustrated in Bock (2013b) is from a section at Bramshaw, Hampshire, England (Voigt Collection).

DiAGNOSIs. - Colony orbicular, bilamellar, discoidal with a perforated peduncle. Median lamella not formed; in cross section opposing autozooecial basal walls alternating in zigzag pattern. Ancestrula circular, no associated kenozooecia observed. Autozooecia grow in slightly regular radial rows, circular with orbicular aperture, the largest arranged at the colony margin, the smallest in the colony centre. Kenozooecia rarely present, usually visible on marginal autozooecia; aperture semilunar with straight or slightly elevated proximal edge. Large subvicarious avicularia present, about half the size of autozooecia, with subcircular aperture and massive pivot bar. Maternal zooecia at or near periphery of colony; owing to the reversed zooecial budding pattern, their ooecia are directed towards colony centre; ooecia subimmersed with bulging skeletal wall that is imperforate but decorated by reticulate, hexagonal sculpturing. A broad median lyrulate structure produced from lower edge of ooecial opening, visible only if aperture is broken. Older zooecia can become closed by secondary calcification and appear as kenozooecia.

\section{REMARKS}

Orbitulipora haidingeri is the type species of the genus. Cheetham (1966) considered it to be a junior synonym of Orbitulipora petiolus Lonsdale, 1850. The lectotype and other syntypes have, however, subvicarious avicularia with a near-circular aperture, kenozooecia distributed among marginal autozooecia, hexagonal decoration of the ooecial surface and a lyrulate structure arising from the lower edge of the ooecium. These features are not present in $O$. petiolus and may be characteristic of O. haidingeri. Cheetham (1966) also described the hyperstomial ovicells of $O$. petiolus as deeply immersed, whereas those of $O$. haidingeri are less immersed. The specimens described by Braga $\&$ Barbin (1988) and Zágoršek (2003) are likely to have been $O$. haidingeri.

Genus Stichoporina Stoliczka, 1862

Stichoporina reussi Stoliczka, 1862 (Fig. 8A-G)

Stichoporina reussi Stoliczka, 1862: 93, pl. 3, fig. 6. Braga 1980: 62. —Zágoršek 2001: 68, pl. 29, figs 1-3. 

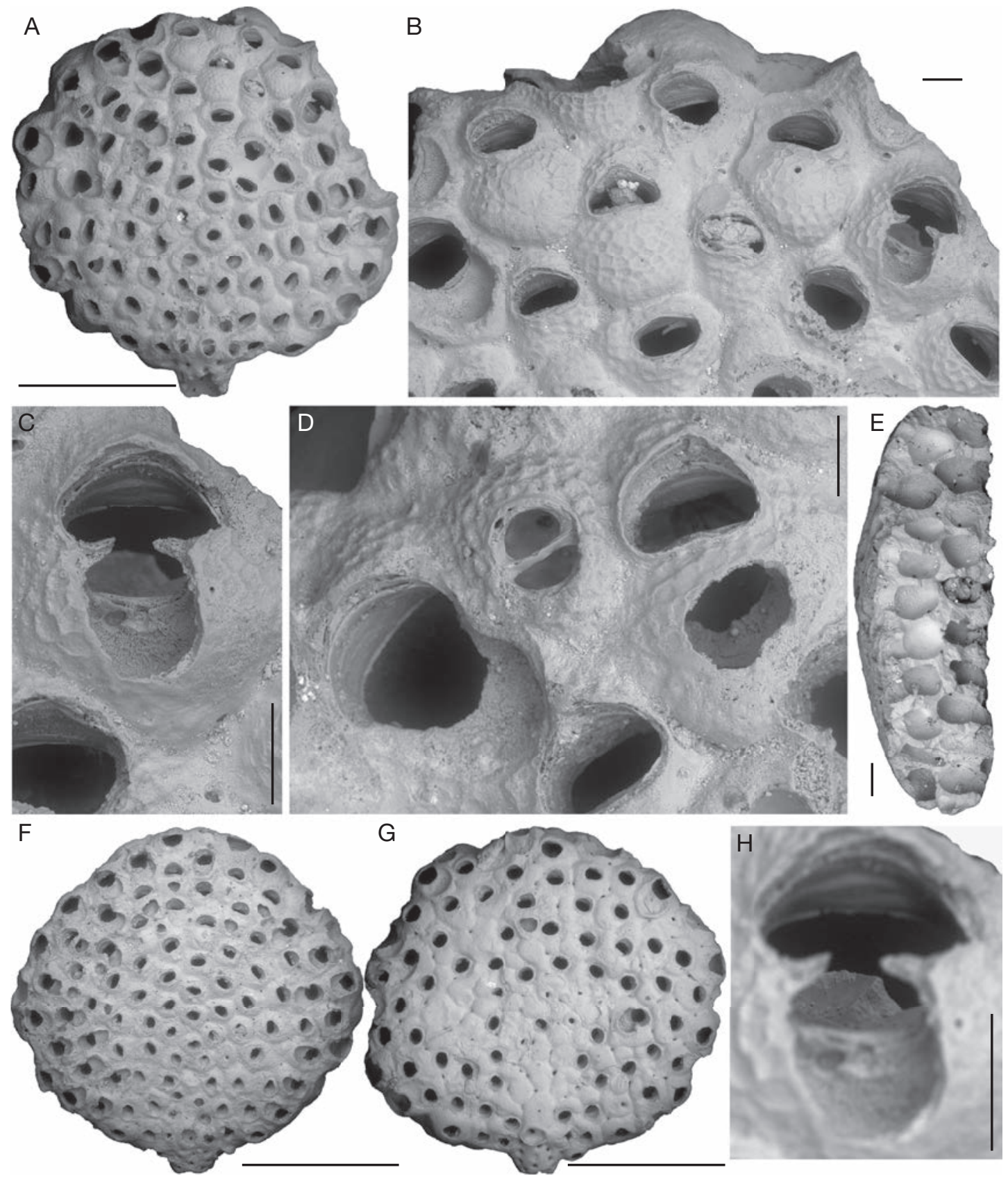

FIG. 7. - Orbitulipora haidingeri Stoliczka, 1862; A, lectotype colony; B, detail of distal colony margin showing ooecia with reticulate surface sculpturing; $\mathbf{C}$, broken ooecial roof in relation to autozooecial aperture; D, large interzooidal avicularium with complete pivot bar; $\mathbf{E}$, transverse section of the colony showing arrangement of autozooecia in two parallel rows; $\mathbf{F}$, a syntype colony with a more regular autozooecial budding pattern; $\mathbf{G}$, syntype with perforated peduncle; $\mathbf{H}$, detail of $\mathbf{C}$ focusing on ledge-like structure at deeper level of aperture. Scale bars: A, F, G, 1 mm; B-E, H, $100 \mu \mathrm{m}$. 

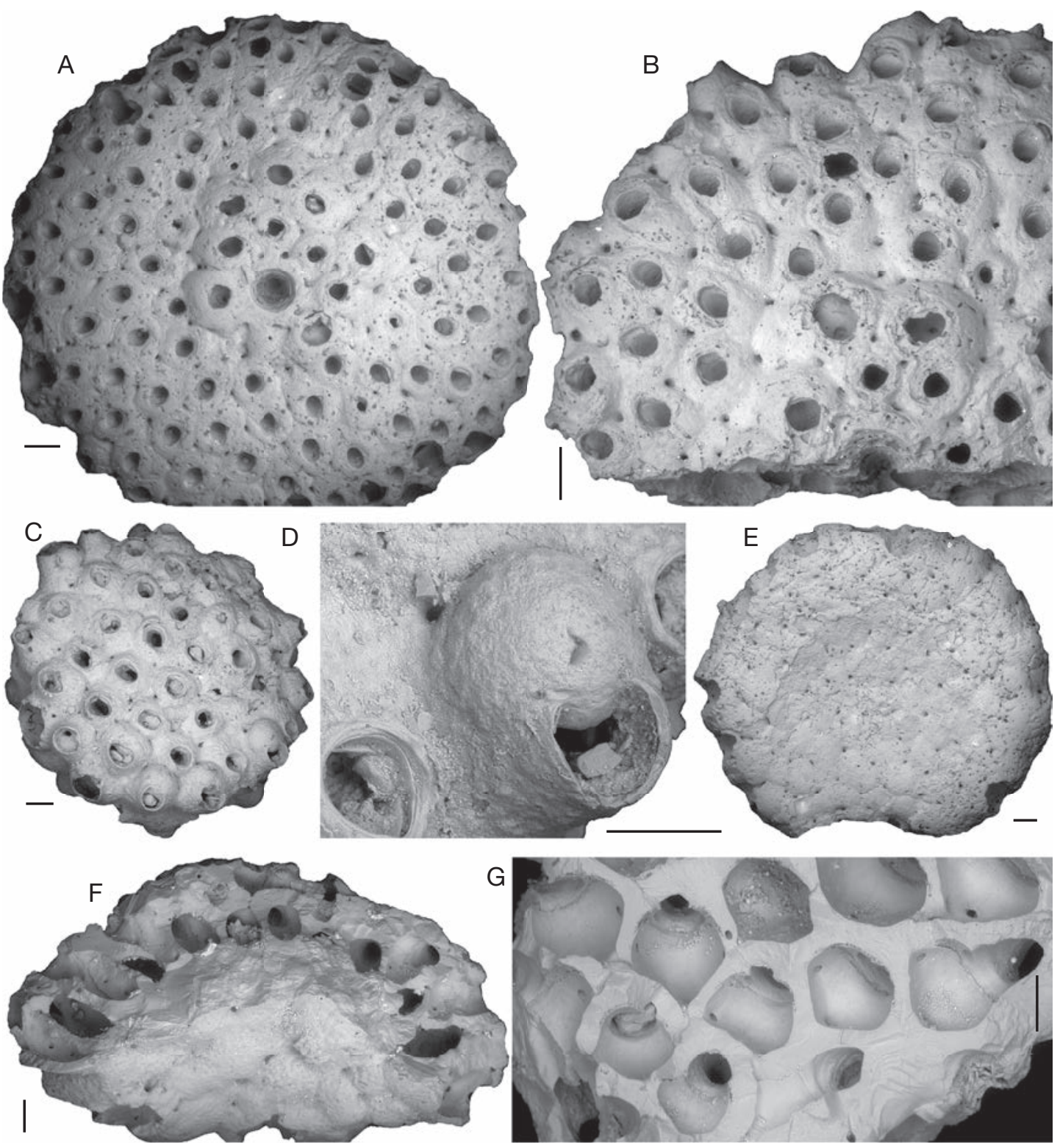

FIG. 8. - Stichoporina reussi Stoliczka, 1862; A, lectotype colony; B, colony margin showing budding pattern; C, a smaller syntype colony; D, detail of ooecium; $\mathbf{E}$, abfrontal view of colony showing a single pore in zooecial basal wall; $\mathbf{F}$, transverse section of colony showing arrangement of autozooecia in one row with a highly calcified central part; G, section showing internal view of autozooecia. Scale bars: $100 \mu \mathrm{m}$.

MATERIAL EXAMineD. - Nine syntypes, registered as 1862/0022/0046. The chosen lectotype (designated here) corresponds with Stoliczka’s illustration (1862: pl. 2, fig. 6) and is depicted as Figure $8 \mathrm{~A}$ herein. The species has been illustrated by Gordon on http://bryozoa.net/cheilostomata/ orbituliporidae/sticreu.html (last access 1st December 2014). 


\section{DESCRIPTION}

Colony discoidal, free-living, with a circular central kenozooidal pit on frontal face and having a concave obverse face. Autozooecia oval to regularly hexagonal with convex frontal shield on upper face of colony; hexagonal with a slightly porous basal wall on lower face; aperture more or less central in zooecium, elongate-oval/subpyriform with short condyles sometimes in evidence. In cross section, autozooecia bottle shaped, with slightly curved distal part. Small kenozooecia with tiny central foramen scattered among autozooecia on upper face. Avicularium usually not present. Ooecia situated on margin of colony, globular with imperforate frontal skeletal wall, slightly immersed in distal autozooecia.

\section{REMARKS}

Stichoporina reussi Stoliczka, 1862 has no avicularia, whereas Stichoporina simplex Koschinsky, 1885 and Stichoporina protecta Koschinsky, 1885 have them. Stichoporina reussi is the type species of the genus, which has been synonymised by Braga (1980) and many other authors with Stenosipora Canu \& Bassler, 1927 (type species Stichoporina protecta). Stenosipora, however, has avicularia, lacks a central pit and basal kenozooecia, and does not form evenly circular colonies. We accept both genera as valid.

\section{DISCUSSION}

In his original paper, Stoliczka (1862) recognized 47 species, 24 of them new. Of these latter, 14 names remain valid; the remainder are synonyms of previously described taxa or, owing to the originally inadequate state of the fossil material examined, taxonomically indeterminable. The genera $\mathrm{Or}$ bitulipora and Stichoporina, both introduced by Stoliczka in 1862 along with their type species, are still valid. Two of his species, one of which had not been examined since its first description, comprise a new bryocryptellid genus, Stoliczkella n. gen., which superficially resembles the celleporid genus Galeopsis.

Oligocene bryozoans are part of the poorly known transitional fauna between very common Eocene and Miocene faunas. Stoliczka (1862) was the first to describe bryozoans from this time span and therefore his paper has both historical and contemporary importance in understanding the European bryozoan fauna. Moreover, many Oligocene taxa show similarities linking Eocene and Miocene bryozoans. Many of Stoliczka's types can be regarded as new and/or as 'living fossils'. For example, a typical Eocene element is represented by the new genus Stoliczkella n. gen., which shows similarities with species described as Galeopsis cf. subquadrangularis from the Eocene of Hungary and Austria (Zágoršek 2001, 2003). Lunulites latdorfensis may be part of the ancestral lineage to Miocene Lunulites androsaces Michelotti, 1838, and Myriapora? beyrichi n. comb. is the earliest myriaporid with an erect growth form, which it has in common with Recent $M$. truncata Pallas, 1766. Both L. androsaces and M. truncata are common in Miocene sediments of the AlpineCarpathian basins (Vávra 1977; Zágoršek, 2010) but are absent from Eocene sediments (Zágoršek 2001, 2003).

As well as adding to our understanding of Oligocene bryozoan faunas in general, this revision of the material examined by Stoliczka (1862) is also the basis for forthcoming research on Oligocene sedimentary sequences in Germany.

\section{Acknowledgements}

This research received support from the SYNTHESYS Project http://www.synthesys.info/which is financed by European Community Research Infrastructure Action under the FP7 "Capacities” Program" for projects AT-TAF-2647 and FR-TAF-2648 to K. Zágoršek. D. P. Gordon's contribution was supported by NIWA under Coasts and Oceans Research Programme 2 (2012/13 SCI). We also thank reviewers Pierre Moissette, Françoise Bigey and Paul Taylor for their valuable comments.

\section{REFERENCES}

Allman G. J. 1856. - A Monograph of the Freshwater Polyzoa, Including all the Known Species, both British and Foreign. The Ray Society, London, vii +119 p.

ArChiac E. J. A. D. DE ST-S. D' 1846. - Description des fossiles recueillis par $\mathrm{M}$. Thorens dans les couches à Nummulines des environs de Bayonne. Mémoires de la Société géologique de France 2: 189-218, 5 pls. 
Bassler R. S. 1953. - Bryozoa, in Moore R. C. (ed.), Treatise on Invertebrate Paleontology, Part G. University of Kansas Press, Lawrence, 253 p.

Blainville H. M. D. DE 1830. - Zoophytes. Dictionnaire des Sciences naturelles 60: 1-546.

BOBIES C. A. 1958. — Bryozoenstudien III/2. Die Horneridae (Bryozoa) des Tortons im Wiener und Eisenstädter Becken. Sitzungberichte der Österreichischen Akademie der Wissenschaften, Mathematisch-naturwissenschaftliche Klasse, Abt. 1, 167: 119-137, 3 pls.

BocK P. E. 2013a. - Tubucella mamillaris, in http:// bryozoa.net/cheilostomata/margarettidae/tubumam. html (last access on $1^{\text {st }}$ December 2014).

Bock P. E. 2013b. — Orbitulipora haidingeri, in http:// bryozoa.net/cheilostomata/orbituliporidae/orbihai. html (last access on 1st December 2014).

BORG F. 1926. - Studies on Recent cyclostomatous Bryozoa. Zoologiska Bidgar frän Uppsala 10: 181507, 10 pls.

Braga G. 1980. - Paleontologia, in ANTOLINI P., BRAGA G. \& FinotTi F. (eds), I Briozoi dei Dintorni di Rovereto - Monte Baldi Settentrionale e Valle di Gresta. Museo Civico, Rovereto: 29-90.

Braga G. \& BARBIN V. 1988. — Les Bryozoaires du Priabonien stratotypique (Province Vicenza, Italie). Revue de Paléobiologie 7: 495-556.

BUSK G. 1852. - An account of the Polyzoa, and sertularian zoophytes, collected in the voyage of the Rattlesnake, on the coasts of Australia and the Louisiade Archipelago, \& c., in MACGILLVRAY J. (ed.), Narrative of the Voyage of H.M.S. Rattlesnake, Commanded by the Late Captain Owen Stanley... 1846-1850; Including Discoveries and Surveys in New Guinea, the Louisiade Archipelago, etc., to which is added the Account of MrE. B. Kennedy's Expedition for the Exploration of the Cape York Peninsula [Including Mr W. Carron's Narrative]. Volume 1. T. W. Boone, London: 343-402, pl. 1.

Busk G. 1854. - Catalogue of Marine Polyzoa in the Collection of the British Museum, II. Cheilostomata (part). Trustees of the British Museum (Natural History), London, viii + pp. 55-120, pls 69-124.

Busk G. 1859. - A Monograph of the Fossil Polyzoa of the Crag. The Palaeontographical Society, London, 136 p., 22 pls.

Busk G. 1860. - Zoophytology. Shetland Polyzoa. Collected by Mr. Barlee. (Continued and concluded). Quarterly Journal of Microscopical Science 8: 213-214, pls 28, 29.

BUSK G. 1884. - Report on the Polyzoa collected by H. M. S. Challenger during the years 1873-76. Part 1. - The Cheilostomata. Report on the Scientific Results of the Voyage of H. M. S. Challenger, Zoology 10 (30): i-xxiv, 1-216, 36 pls.

CANU F. 1913. - Études morphologiques sur trois nouvelles familles de Bryozoaires. Bulletin de la Société géologique de France, sér. 4, 13: 132-147.
CANU F. 1918. - Les ovicelles des Bryozoaires cyclostomes. Bulletin de la Société géologique de France, sér. 4, 16 [for 1916]: 324-335.

CANU F. \& BASSLER R. S. 1917. - A synopsis of American Early Tertiary cheilostome Bryozoa. United States National Museum Bulletin 96: 1-87, 6 pls.

CANU F. \& BASSLER R. S. 1923. - North American later Tertiary and Quaternary Bryozoa. Bulletin of the United States National Museum 125: i-viii, 1-302, 47 pls.

Cheetham A. H. 1966. - Cheilostomatous Polyzoa from the Upper Bracklesham Beds (Eocene) of Sussex. Bulletin of the British Museum (Natural History), Geology 13: 1-115.

DAVID L., POUYET S. 1974. — Révision des Bryozoaires cheilostomes miocènes du Bassin de Vienne-Autriche. Documents des Laboratoires de Géologie de la Faculté des Sciences de Lyon 60: 83-258, 15 pls.

David L., Mongereau N. \& Pouyet S. 1972. - Bryozoaires du Néogène du Bassin du Rhône. Gisements burdigaliens de Mus (Gard). Documents des Laboratoires de Géologie de la Faculté des Sciences de Lyon 52: 1-118.

Ehrenberg G. 1831. - Symbolae Physicae, seu icons et descriptions corporum naturalium novorum aut minus cognitorum, quae ex itineribus per Libyam, Aegyptum, Nubiam, Dongalam, Syriam, Arabiam et Habissiniam... studio annis 1820-25 redierunt... Pars Zologica. Vol. 4, Animalia Evertebrata exclusis Insectis. Berolini, 10 pls.

GabB W. M. \& Horn G. H. 1862. - The fossil Polyzoa of the Secondary and Tertiary Formations of North America. Journal of the Academy of Natural Sciences of Philadelphia 5: 111-179, pls 19-21.

GORDON D. P. 1984. - The marine fauna of New Zealand: Bryozoa: Gymnolaemata from the Kermadec Ridge. New Zealand Oceanographic Institute Memoir 91: 1-198.

Gordon D. P. \& HondT J.-L. D’ 1997. — Bryozoa: Lepraliomorpha and other Ascophorina, mainly from New Caledonian waters, in CROSNIER A. (ed.), Résultats des Campagnes MUSORSTOM, Volume 18. Mémoires du Muséum national d'Histoire naturelle (A), 176: 9-124.

Gordon D. P. \& TAYLOR P. D. (in press). - Bryozoa of the Early Eocene Tumaio Limestone, Chatham Island. Journal of Systematic Palaeontology.

GraY J. E. 1840 [1841]. - Synopsis of the Contents of the British Museum. 42nd Edn. Trustees of the British Museum (Natural History), London, $370 \mathrm{p}$.

GraY J. E. 1848. - List of the Specimens of British Animals in the Collection of the British Museum. Part 1. Centroniae or Radiated Animals. Trustees of the British Museum (Natural History), London, xiii + 173 p.

Gregory J. W. 1893. - On the British Palaeogene Bryozoa. Transactions of the Zoological Society of London 13: 219-279, pls 29-32.

GREGORY J. W. 1899. - Catalogue of the Fossil Bryozoa in the Department of Geology, British Museum (Natural 
History). The Cretaceous Bryozoa. Volume I. Trustees of the British Museum (Natural History), London, xiv +457 p., 17 pls.

Hagenow F. VON 1851. - Die Bryozoen der Maastrichter Kreidebildung. Theodor Fischer, Cassel, xvi + 111 p., 12 pls.

Harmer S. F. 1957. - The Polyzoa of the Siboga Expedition. Part 4. Cheilostomata Ascophora. II. SibogaExpeditie 28d: i-xv, 641-1147, pls 42-74.

HINCKS T. 1884. - Contributions towards a general history of the marine Polyzoa. XIV. Polyzoa from New Zealand and Australia. XV. Cheilostomata Miscellaneous. Annals and Magazine of Natural History, ser. 5, 13: 356-369, pls 13, 14.

HoNDT J.-L. D' 1985. - Contribution à la systématique des Bryozoaires Eurystomes. Apports récents et nouvelles propositions. Annales des Sciences naturelles, Zoologie, sér. 13, 7: 1-12.

JoHnSTON G. 1838. - A History of the British Zoophytes. W. H. Lizars, Edinburgh, London \& Dublin, xii + 341 p., 44 pls.

JOHNSTON G. 1847. - A History of the British Zoophytes. $2^{\text {nd }}$ edn. John Van Voorst, London, Vol. 1, xvi + 488 p.; Vol. 2, 74 pls.

Jullien J. 1881. - Remarques sur quelques espèces des Bryozoaires cheilostomiens. Bulletin de la Société zoologique de France 6: 163-168.

JULLIEN J. 1882. - Note sur une nouvelle division de Bryozoaires cheilostomiens. Bulletin de la Société zoologique de France 6: 271-285.

Jullien J. 1883. — Dragages du 'Travailleur', Bryozoaires. Espèces draguées dans l'Océan Atlantique en 1881. Bulletin de la Société zoologique de France 6: 497-534, pls 13-17.

JulliEN J. 1888. - Bryozoaires. Mission scientifique du Cap Horn 1882-1883, 6 (Zoologie 3): 1-92, 15 pls.

JULLIEN J. \& CALVET L. 1903. - Bryozoaires provenant des campagnes de l'Hirondelle. Résultats des Campagnes scientifiques accomplies par le Prince Albert I23: 1-188, 18 pls.

KOSCHINSKY C. 1885. - Ein beitrag zur Kenntnis der Bryozoenfauna der älteren Tertiärschichten des südlichen Bayerns. (I. Abth Cheilostomata). Palaeontographica 32: 1-73, pls 1-7.

LAMARCK J. B. P. A. DE 1816. - Les Polypes. Histoire naturelle des Animaux sans Vertèbres 2: 1-586.

LAMOuroux J. V. F. 1821. - Exposition méthodique des genres de l'ordre des Polypiers, avec leur description et celles des principales espèces figurées dans 84 planches; les 63 premières apartenant à l'Histoire naturelle des Zoophytes d'Ellis et Solander. V. Agasse, Paris, viii + 115 p., 84 pls.

LEVINSEN G. M. R. 1909. - Morphological and Systematic Studies on the Cheilostomatous Bryozoa. Nationale Forfatteres Forlag, Copenhagen, vii + 431 p, 24 pls. LONSDALE W. 1850. — [Descriptions of Eocene fossils from Bracklesham Bay and Selsey.] Zoophyta or corals, in Dixon F. (ed.), The Geology and Fossils of the Tertiary and Cretaceous Formations of Sussex. Longman, Brown, Green \& Longmans, London: 125-161, pl. 1.

MacGillivray P. H. 1886. - Descriptions of new, or little-known, Polyzoa. Part IX. Transactions and Proceedings of the Royal Society of Victoria 22: 128-139, 3 pls.

MANZONI A. 1878. - I Briozoi fossili del Miocene d'Austria ed Ungheria. III. Parte. Crisidea, Idmoneidea, Entalophoridea, Tubuliporidea, Diastoporidea, Cerioporidea. Denkschriften der Akademie der Wissenschaften 38: 1-24, 18 pls.

Milne EdWARDS H. 1836. - Observations sur les Polypiers fossiles du genre Eschare. Annales des Sciences naturelles, sér. 2, 6: 321-345, 3 pls.

Milne Edwards H. 1838. - Mémoire sur les Crisies, les Hornères et plusieurs autres Polypes. Annales des Sciences naturelles, sér. 2, 9: 193-238, 7 pls.

Nehyba S., Tomanová-Petrová P. \& Zágoršek K. 2008. - Sedimentological and palaeocological records of the evolution of the south western part of the Carpathian Foredeep (Czech Republic) during the early Badenian. Geological Quarterly 52 (1): 45-60.

Orbigny A. D. D' 1851-54. - Bryozoaires. Paléontologie française. Description des Mollusques et Rayonnées fossiles. Terrains crétacés 5: 1-188 (1851), 185bis-472 (1852), 473-984 (1853), 985-1192 (1854), pls 600-800.

POUYET S., DAVID L. 1979. — Révision systématique du genre Steginoporella Smitt, 1873 (Bryozoa Cheilostomata). Géobios 12: 763-817.

Reuss A. E. 1847. - Die fossilen Polyparien des Wiener Tertiärbeckens. Naturwissenschaftliche Abhandlungen 2: 1-109, 11 pls.

Reuss A. E. 1851. - Ein Beitrag zur Paläontologie der Tertiärschichten von Oberschlesien. Zeitschrift Deutschen Geologischen Gesellschaft 3: 149-184, pls 8, 9.

Reuss A. E. 1866. - Die Foraminiferen, Anthozoen und Bryozoen des deutschen Septharienthones. Ein Beitrag zur Fauna der Mitteloligocanen Tertiärschichten. Denkschriften der koenigliche Akademie der Wissenschaften in Wien 25: 117-213.

Reuss A. E. 1867. — Über einige Bryozoen aus dem deutschen Unteroligozän. Sitzungsberichte der koenigliche Akademie der Wissenschaften in Wien 55: 216-234.

Reuss A. E. 1869. - Paläontologische Studien über die älteren Tertiärschichten der Alpen. II. Abtheilung. Die fossilen Anthozoen und Bryozoen der Schichtengruppe von Crosara. Denkschriften der koenigliche Akademie der Wissenschaften in Wien 29: 215-298, 20 pls.

SMith A. M., TAYlor P. D. \& SPENCER H. G. 2008. - Resolution of taxonomic issues in the Horneridae (Bryozoa: Cyclostomata), in WySE JACKSON P. N. \& SPENCER JONES M. E. (eds), Annals of Bryozoology 2. International Bryozoloogy Association, Dublin: 359-411.

SMiTT F. A. 1867. - Kritisk förteckning öfver Skandinaviens Hafs-Bryozoer. II. Öfversigt af Kongliga 
Vetenskaps-Akademiens Förhandlingar 23: 395-533, pls 3-13.

SMITT F. A. 1868. - Kritisk förteckning öfver Skandinaviens Hafs-Bryozoer. IV. Öfversigt af Kongliga Vetenskaps-Akademiens Förhandlingar 24: 3-230, pls 24-28.

SmiTt F. A. 1873. - Floridan Bryozoa, collected by Count L. F. de Pourtales. Part II. Kongliga Svenska Vetenskaps-Akademiens Handlingar 11 (4): 1-83, 13 pls.

STOLICZKA F. 1862. - Oligocäne Bryozoen von Latdorf in Bernburg. Sitzungsberichte der Preussischen Akademie der Wissenschaften zu Berlin 45: 71-94, pls 1-3.

VaVRa N. 1977. — Bryozoa tertiaria. Catalogus Fossilium Austriae 5b/3: 1-210.

VigneAuX M. 1949. — Révision des Bryozoaires néo- gènes du Bassin d'Aquitaine et essai de classification. Mémoires de la Société géologique de France, n.s., 28: $1-153,11$ pls.

Waters A. W. 1887. - On Tertiary cyclostomatous Bryozoa from New Zealand. Quarterly Journal of the Geological Society of London 43: 337-350, pl. 18.

ZÁGORŠEK K. 2001. — Eocene Bryozoa from Hungary (part II. Systematic palaeontology). Courier Forschungsinstitut Senckenberg 231: 19-159.

ZÁGORŠEK K. 2003. - Upper Eocene Bryozoa from Waschberg Zone (Austria). Beiträge zur Paläontologie 28: 101-263.

ZÁGORŠEK K. 2010. - Bryozoa from the Langhian (Miocene) of the Czech Republic. Acta Musei Nationalis Pragae, ser. B, Historia Naturalis 66: 3-255.

Submitted on 12 November 2013; accepted on 3rd July 2014; published on 26 December 2014. 